\title{
Research Collaborations Between Universities and Department of Defense Laboratories
}

\author{
Nayanee Gupta \\ Brian J. Sergi \\ Emma D. Tran \\ Rashida Nek \\ Susannah V. Howieson
}

July 2014

Approved for public release; distribution is unlimited.

IDA Document D-5230

Log: H 14-000752

IDA SCIENCE \& TECHNOLOGY

1899 Pennsylvania Ave., Suite 520

Washington, DC 20006-3602 

three federally funded research and development centers to provide objective analyses of national security issues, particularly those requiring scientific and technical expertise, and conduct related research on other national challenges.

About This Publication

This work was conducted by the IDA Science and Technology Policy Institute under contract NSFOIA0408601, Task TP-20-1000.00.AU, "An Examination of Department of Defense Laboratory-University Partnerships," for the Office of Science and Technology Policy. The views, opinions, and findings should not be construed as representing the official positions of the National Science Foundation or the Office of Science and Technology Policy in the Executive Office of the President.

Acknowledgments

The authors appreciate the input provided by the technical reviewers on this task, Christopher L. Weber and Asha Balakrishnan of the IDA Science and Technology Policy Institute.

Copyright Notice

(c) 2014 Institute for Defense Analyses

4850 Mark Center Drive, Alexandria, Virginia 22311-1882 • (703) 845-2000.

This material may be reproduced by or for the U.S. Government pursuant to the copyright license under the clause at FAR 52.227-14 (December 2007). 
SCIENCE \& TECHNOLOGY POLICY INSTITUTE

IDA Document D-5230

\title{
Research Collaborations Between Universities and Department of Defense Laboratories
}

\author{
Nayanee Gupta \\ Brian J. Sergi \\ Emma D. Tran \\ Rashida Nek \\ Susannah V. Howieson
}





\section{Executive Summary}

Collaborative research partnerships between universities and Department of Defense (DOD) laboratories are important to national and homeland security missions. From the point of view of the laboratories, university collaborations help them to deliver world-class research while providing the opportunity to develop and grow a talent pipeline. Benefits to universities range from the opportunity to work on cutting-edge problems of national importance to gaining access to specialized research facilities and potential channels for funding.

This report examines the current landscape of DOD laboratory-university research partnerships and recommends steps to reduce barriers faced in these undertakings and to increase the number of collaborations between the two entities. The work was informed by structured discussions with members of the research community and research leaders at universities and DOD laboratories. The overarching insights gained from these individuals experience with such collaborative partnerships are:

- DOD laboratories seek partnerships that support their missions. The scope and extent of the DOD laboratories' technical collaboration with universities is governed by their mission-based operational needs. Thus, research partnerships are primarily initiated when DOD laboratories see an unmet need and reach out to external experts. A corollary to this is that universities should view the DOD as a customer whose partnerships will be focused in DOD areas of need. Within this context, the onus is on the university to understand the laboratory's research needs, propose ideas for collaboration, and seek ways to improve their visibility to the laboratories.

- Currently available mechanisms for long-term partnerships are adequate for DOD needs, but stronger short-term partnership mechanisms are needed. From the perspective of DOD research leadership interviewed for this task, the research partnership agreements that DOD laboratories currently have in place with universities (i.e., the larger and longer term collaborations such as Cooperative Research and Development Agreements, Collaborative Research Agreements/Cooperative Technical Agreements, and University Affiliated Research Centers) are adequate for their needs. This view did not extend to personnel exchanges, educational partnerships, and other short-term agreements, which the DOD research leadership strongly endorsed, and would like to see strengthened. If the goal is to increase the number of long-term and large-scale research partnership agreements between the two communities, DOD's 
satisfaction with the existing number and type of partnership agreements warrants a policy discussion that is beyond the scope of this report.

- People are central to improving partnerships. This tenant was a consistent underlying theme in the discussions. Developing professional relationships and connecting the right people is the most important element in beginning and continuing long-term collaborations. Cultivating and maintaining research partnerships strengthens the talent pipeline to the national security science and technology enterprise. Student and post-doctoral exchanges to build future connections between universities and the laboratories.

- Successful partnerships start small and take time to develop. Several discussants mentioned that the process of building successful partnerships is incremental and typically grows slowly from small projects and over a long time. Sometimes, the line between grant funding and collaborations is blurry, as one usually evolves into the other.

- Mutual awareness of opportunities and liabilities should be improved.

Discussants from both universities and DOD laboratories said that the status quo could be improved by increasing mutual awareness of laboratory and university research strengths and educating universities on the "rules of the road" (e.g., ethical and legislative liabilities) and the opportunities available at DOD laboratories. 


\section{Contents}

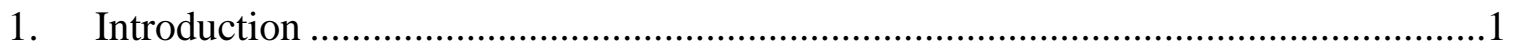

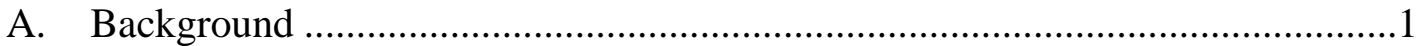

B. Methodology and Report Overview ..............................................................2

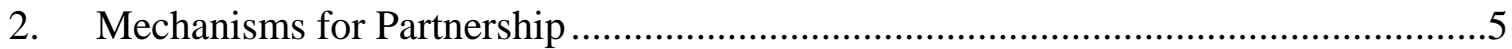

3. Awareness, Access, and Need for Collaboration ..................................................

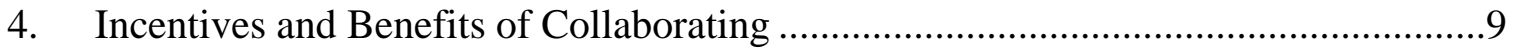

A. Incentives for the DOD to Collaborate........................................................9

1. Extending the Breadth and Depth of the DOD's Research Efforts ...............9

2. Providing Topical Area Expertise ...........................................................9

3. Leveraging University Facilities and Resources .......................................10

4. Linking Federal and Third-Party Stakeholders ........................................10

B. Incentives for the Universities....................................................................... 10

1. Enhancing Academic Efforts of University Researchers ..........................10

2. Providing Access to Specialized Facilities at DOD Laboratories...............11

3. Partnering with the DOD in a Collaborative Environment .........................11

4. Providing Opportunities for Students ......................................................11

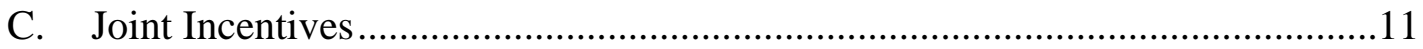

1. Faculty and Student Exchange: Building a Talent Pipeline .........................11

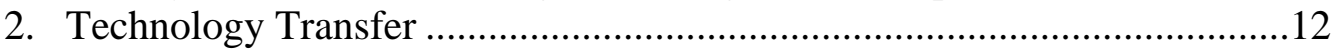

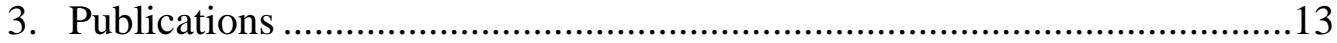

5. Overcoming Challenges and Leveraging Other Considerations Regarding DOD Laboratory and University Research Collaborations ....................................15

A. Challenges to Initiating Collaborations .....................................................15

1. Lack of Awareness of and Misconceptions about the DOD by

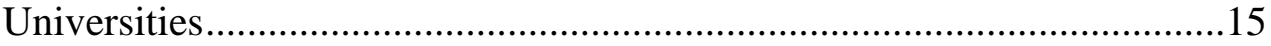

2. Classification or Security Restrictions May Impede Collaboration ............17

3. Perception of Legal, Ethical, or Security Restrictions by Would-be Collaborators at DOD Laboratories ..........................................................18

4. General Uncertainty about Funding Arrangements...................................20

5. Increased Patent Filing Fees when Partnering with Government Entities.......................................................................21

B. Other Considerations for Enhanced Collaboration Opportunities ....................22

1. Need for Personal Connections ...............................................................22

2. Value of Physical Location and Proximity ................................................24

6. Summary of Challenges and Recommendations ................................................27

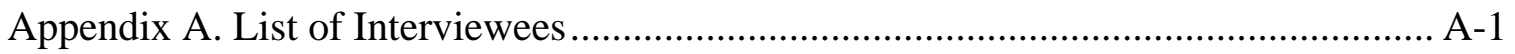

Appendix B. Examples of Laboratory-University Interactions ...................................... B-1 
Appendix C. Interview Protocol ..................................................................................... Appendix D. A Guidebook for Universities Partnering with the Department of

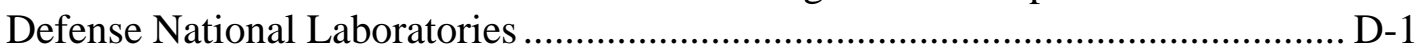

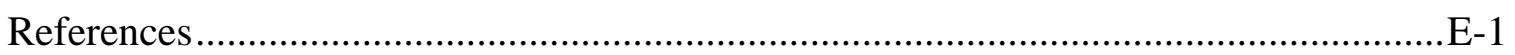

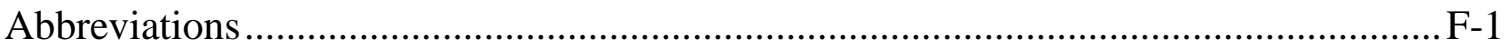




\section{Introduction}

\section{A. Background}

Federal laboratories have a long history of research partnerships with universities, and these collaborations are viewed as being important to strengthening the nation's research enterprise, particularly in areas related to national security. A National Academies report ${ }^{1}$ of a 2005 workshop on the importance of collaboration between Federal, primarily Department of Energy (DOE), laboratories and universities discusses the many benefits of such collaborations to both communities. Today, Federal laboratories across multiple agencies are reexamining their relationships to universities and exploring new models and avenues for collaboration that can provide increased value to both parties.

The Department of Defense (DOD) laboratories are engaged in mission-oriented research that requires expertise in multiple scientific and technical disciplines. From the laboratory's point of view, university collaborations at all levels are important for strengthening their ability to deliver world-class research. In addition, these collaborations allow the laboratories to train and recruit students in specialized areas. ${ }^{2}$ From the university perspective, such collaborations provide opportunities to work on critical national problems and simultaneously grow the talent pipeline in critical areas of science and technology (S\&T). ${ }^{3}$

Currently, however, such mutually beneficial partnerships are not as abundant as those in the intramural research programs at the DOE. Part of this dearth of partnerships can be attributed to the fact that DOD laboratories initiate partnerships only when they seek out external expertise in very specific areas of need. Typically DOD laboratories fund more research by others more often than they engage in research partnerships. Among universities seeking to engage with the DOD, lack of information about and familiarity with the agency's culture and research needs are seen as challenges. Discussions with personnel at DOD laboratories indicate that research topics suggested by university

1 National Research Council, National Laboratories and Universities: Building New Ways to Work Together - Report of a Workshop, (Washington, DC: The National Academies Press, 2005), http://www.nap.edu/catalog/11190.html.

2 For example, see R. Hummel and P. Cheetham, “A DOD Perspective on STEM Education,” Synesis: A Journal of Science, Technology, Ethics, and Policy 2012 (Potomac Institute Press, 2010-2012), http://www.synesisjournal.com/vol3_t/Hummel_2012_T25-36.pdf.

3 National Research Council (NRC), Assuring the U.S. Department of Defense a Strong Science, Technology, Engineering, and Mathematics (STEM) Workforce (Washington, DC: The National Academies Press, 2012), http://www.nap.edu/catalog.php?record_id=13467. 
researchers often do not gain traction unless specifically aligned with current or anticipated DOD mission needs (in contrast to the comparatively more open-ended research solicited by other research-oriented agencies).

Universities that currently interact with DOD laboratories are those that have seen a clear benefit to this interaction and have invested time and effort to facilitate connections, both at the researcher level and at the administrative/contractual level of university leadership.

The Office of Science and Technology Policy (OSTP) is interested in ways to increase and streamline partnerships between national security Federal laboratories and universities to maximize the collaborative interactions and cultivate relationships with more universities. To this end, OSTP tasked the IDA Science and Technology Policy Institute (STPI) with exploring how collaborative partnerships between DOD laboratories and universities typically evolve, what mechanisms are available for this, and the opportunities and barriers as perceived by both research communities (i.e., DOD laboratories and universities).

As part of this task, STPI produced a separate guidebook that focuses on the partnership mechanisms by which universities and DOD laboratories can engage in jointeffort collaborative research. The guidebook, reproduced in this document as Appendix D, is a primer for universities that seek to establish a collaborative relationship with DOD laboratories and is intended to demystify the process of approaching and establishing technical partnerships with DOD laboratories. The guidebook was provided to participants at a Washington, DC, region DOD/Academia Partnership Colloquium held at Georgetown University in December 2013.

This document illustrates some of the reasons that collaborations between the DOD laboratories and the universities are more limited than may be desirable. It identifies and explains the motivations to research partnering on both sides so that they might be harnessed to create incentives for expanding such endeavors). It also provides details about how both research communities perceive what drives successful partnerships and what prevents them. Finally, based on interviews of various university and DOD research personnel, the document offers policy suggestions to remove or lessen the impact of remaining barriers to collaboration.

\section{B. Methodology and Report Overview}

Data collection for this task was based primarily on structured discussions with 16 representatives from various DOD funding agencies and laboratories, five university researchers and vice presidents of research who have worked with the DOD, and the leadership at four universities that currently engage with DOD laboratories. OSTP facilitated the data gathering and publicized the task by participating in or hosting a series of events over the summer of 2013 to convene key stakeholders. These events included: (1) the Assistant Secretary of Defense for Research and Engineering (ASD[R\&E]) 
Technical Workshop with the National Security Science and Engineering Faculty Fellows (NSSEFF) to discuss possible technical partnering opportunities from the ASD(R\&E) Priority Steering Committees, (2) a workshop with NSSEFF university business offices to discuss successes and barriers to supporting partnering between the university and DOD laboratories, and (3) a White-House-sponsored meeting with select panel of university vice presidents/provosts, Office of the Secretary of Defense leadership, and DOD Laboratory Directors to discuss challenges and announce increased partnerships. The list of discussants for the present work (see Appendix A) was drawn from DOD and university participants at these events. (Interviews for this report were conducted separately from these events.)

The discussion protocol sought information on previous and current collaborations, motivations for collaborating, barriers to collaborations, and metrics for success. Input from these discussions was synthesized to extract insights on the possible motivations that the universities and DOD laboratories might have for collaborating, to examine barriers to this process, and to provide suggestions and policy changes that could foster more collaborative research. STPI researchers also reviewed the literature on DOD laboratory research and funding mechanisms to provide additional background on topics introduced by the interviewees.

While the information presented in this report is applicable to DOD laboratories as a whole, variations and distinctions exist among the Army, Navy, and Air Force in terms of the structure of their laboratories, the types of collaborative research they conduct, and how best to engage them in research given their diverse mission-driven needs.

The remaining chapters of this report unfold as follows:

- Chapter 2 describes the available mechanisms for DOD-academic research partnerships

- Chapter 3 examines some overarching issues that have shaped the current state of collaborative research between the DOD laboratories and universities

- Chapter 4 lists some of the motivations to pursue technical research collaboration from the perspectives of DOD and the universities.

- Chapter 5 examines the barriers to initiating and cultivating technical collaborations, in addition possible policy actions to be taken.

- Chapter 6 summarizes the recommendations to mitigate the effect of current barriers and improve the status quo. 



\section{Mechanisms for Partnership}

Partnerships between universities and DOD laboratories can take many different forms. Some examples include Cooperative Research and Development Agreements (CRADAs), Collaborative Research Alliances (CRAs), Collaborative Technical Alliances (CTAs), and University Affiliated Research Centers (UARCs). While the DOD does provide grant-based programs for academic institutions, collaborative partnerships between universities and DOD laboratories typically entail the bi-directional exchange of workforce, materials, intellectual property, or basic ideas. (A guidebook describing the various mechanisms in further detail is reproduced as Appendix D.)

This chapter briefly describes the different types of mechanisms that are available for collaborative research partnerships between DOD laboratories and universities. Table 1 summarizes the agreement mechanisms available, which are categorized thematically as follows:

- Research partnership agreements. These agreements provide for joint and collaborative research.

- Resource-use agreements. These agreements allow non-Federal partners to use Federal laboratory equipment for testing and evaluation.

- Personnel exchange agreements. These agreements enable researchers (usually those more advanced in their careers) from one organization to be employed temporarily or indefinitely by another organization.

- Educational agreements. These agreements offer opportunities to undergraduate and graduate students, post-doctoral fellows, and professors to extend their education and research experience and for universities to co-develop educational initiatives with Federal laboratories.

- Other types of agreements. Agreements with Centers of Excellence and University Affiliated Research Centers (UARCs) or through other transaction authorities.

Appendix B contains an extensive list of examples of research partnerships between DOD laboratories and universities, showing the diverse areas of expertise sought at universities, the partnering mechanism used, and the durations of the collaborations. 
Table 1.Types of Mechanisms Available for Collaborative Research Partnerships between DOD Laboratories and Universities

\begin{tabular}{|c|c|c|c|c|c|c|c|}
\hline $\begin{array}{c}\text { Type of } \\
\text { Agreement }\end{array}$ & $\begin{array}{l}\text { Agreement or } \\
\text { Mechanism }\end{array}$ & Primary Purpose & $\begin{array}{c}\text { Approximate } \\
\text { Length }\end{array}$ & $\begin{array}{l}\text { Collaboration } \\
\text { in Research }\end{array}$ & $\begin{array}{l}\text { Personnel } \\
\text { Exchange }\end{array}$ & $\begin{array}{l}\text { Laboratory } \\
\text { Facilities } \\
\text { Access }\end{array}$ & $\begin{array}{l}\text { Funds } \\
\text { from } \\
\text { the } \\
\text { Gov. }\end{array}$ \\
\hline \multirow{4}{*}{$\begin{array}{l}\text { Research } \\
\text { Partnership } \\
\text { Agreements }\end{array}$} & $\begin{array}{l}\text { Cooperative } \\
\text { Research and } \\
\text { Development } \\
\text { Agreement } \\
\text { (CRADA) }\end{array}$ & $\begin{array}{l}\text { Contract for collaborative } \\
\text { research. Often used when the } \\
\text { production of a commercial } \\
\text { technology is expected. }\end{array}$ & $\begin{array}{l}\text { Medium to } \\
\text { long term }\end{array}$ & Yes & Yes & Yes & No \\
\hline & $\begin{array}{l}\text { Non-traditional } \\
\text { CRADA }\end{array}$ & $\begin{array}{l}\text { CRADA tailored for specialized } \\
\text { purposes (e.g., clinical trial } \\
\text { partnerships, materials } \\
\text { transfer). }\end{array}$ & $\begin{array}{l}\text { Medium to } \\
\text { long term }\end{array}$ & Yes & Yes & Yes & No \\
\hline & $\begin{array}{l}\text { Cooperative } \\
\text { Agreement }\end{array}$ & $\begin{array}{l}\text { Used for collaborative research } \\
\text { projects that are exploratory in } \\
\text { nature. Must be competed. }\end{array}$ & $\begin{array}{l}\text { Medium to } \\
\text { long term }\end{array}$ & Yes & Yes & Yes & Yes \\
\hline & $\begin{array}{l}\text { Collaborative } \\
\text { Research/ } \\
\text { Technology } \\
\text { Alliance } \\
\text { (CRA/CTA) }\end{array}$ & $\begin{array}{l}\text { A special form of cooperative } \\
\text { agreement that emphasizes } \\
\text { multi-disciplinary collaboration } \\
\text { and often combines } \\
\text { government, industry, and } \\
\text { university partners. Must be } \\
\text { competed. }\end{array}$ & $\begin{array}{l}\text { Medium to } \\
\text { long term }\end{array}$ & Yes & Yes & Yes & Yes \\
\hline \multirow{3}{*}{$\begin{array}{l}\text { Resource-Use } \\
\text { Agreements }\end{array}$} & $\begin{array}{l}\text { Commercial Test } \\
\text { Agreement }\end{array}$ & $\begin{array}{l}\text { Allows partners to test } \\
\text { materials, equipment, models, } \\
\text { or software using government } \\
\text { laboratory equipment. }\end{array}$ & Short term & No & No & Yes & No \\
\hline & $\begin{array}{l}\text { Test Service } \\
\text { Agreement }\end{array}$ & $\begin{array}{l}\text { Allows partners to purchase } \\
\text { testing services for materials, } \\
\text { equipment, models, or software } \\
\text { from government laboratories. }\end{array}$ & Short term & No & No & Yes & No \\
\hline & $\begin{array}{l}\text { User Facilities } \\
\text { Agreement }\end{array}$ & $\begin{array}{l}\text { Enables partners to conduct } \\
\text { research experiments on } \\
\text { unique government laboratory } \\
\text { equipment and facilities. }\end{array}$ & Short term & No & No & Yes & No \\
\hline \multirow{2}{*}{$\begin{array}{l}\text { Personnel } \\
\text { Exchange } \\
\text { Agreements }\end{array}$} & $\begin{array}{l}\text { Intergovernmental } \\
\text { Personnel Act } \\
\text { (IPA) } \\
\text { Assignments }\end{array}$ & $\begin{array}{l}\text { Used for exchanges of Federal } \\
\text { laboratory and university } \\
\text { personnel. }\end{array}$ & Short term & No & Yes & No & No \\
\hline & $\begin{array}{l}\text { Joint } \\
\text { Appointments }\end{array}$ & $\begin{array}{l}\text { Allows university or Federal } \\
\text { laboratory personnel to be } \\
\text { employed at multiple } \\
\text { institutions. }\end{array}$ & $\begin{array}{l}\text { Medium to } \\
\text { long term }\end{array}$ & No & Yes & No & No \\
\hline \multirow{2}{*}{$\begin{array}{l}\text { Educational } \\
\text { Agreements }\end{array}$} & $\begin{array}{l}\text { Educational } \\
\text { Partnership } \\
\text { Agreements }\end{array}$ & $\begin{array}{l}\text { Used to allow government } \\
\text { laboratories and universities to } \\
\text { work together to develop } \\
\text { educational programs that } \\
\text { further both partners' missions. }\end{array}$ & Medium term & Varies & Varies & Varies & Varies \\
\hline & $\begin{array}{l}\text { Fellowship, } \\
\text { Internship, and } \\
\text { Sabbatical Leave } \\
\text { Programs }\end{array}$ & $\begin{array}{l}\text { A variety of mechanisms } \\
\text { available for students and } \\
\text { research professors, including } \\
\text { summer internships and } \\
\text { fellowships and faculty leave } \\
\text { programs. Vary by Service. }\end{array}$ & Short term & Varies & Yes & Varies & Varies \\
\hline \multirow{3}{*}{$\begin{array}{l}\text { Other } \\
\text { Partnership } \\
\text { Agreements }\end{array}$} & $\begin{array}{l}\text { University } \\
\text { Affiliated } \\
\text { Research Center } \\
\text { (UARC) }\end{array}$ & $\begin{array}{l}\text { Long-term partnerships that } \\
\text { create a university-led research } \\
\text { center to meet DOD needs. } \\
\text { Must be competed. Cannot be } \\
\text { solicited. }\end{array}$ & Long term & Yes & Yes & No & Yes \\
\hline & $\begin{array}{l}\text { Centers of } \\
\text { Excellence }\end{array}$ & $\begin{array}{l}\text { An Air Force mechanism that is } \\
\text { similar to that of the UARC. } \\
\text { Must be competed. Cannot be } \\
\text { solicited. }\end{array}$ & Long term & Yes & Yes & No & Yes \\
\hline & $\begin{array}{l}\text { Other Transaction } \\
\text { Authority }\end{array}$ & $\begin{array}{l}\text { Used for a partnership that } \\
\text { does not fit the two previous } \\
\text { agreement mechanisms. } \\
\text { Special conditions apply. }\end{array}$ & Varies & Varies & Varies & Varies & Varies \\
\hline
\end{tabular}




\section{Awareness, Access, and Need for Collaboration}

Discussions with DOD laboratory personnel revealed that the scope and extent of DOD laboratories' technical collaborations with universities are shaped by the fact that DOD laboratories (and the DOD as a whole) have specific mission-based operational needs that tie into their technical requirements. As such, the laboratories are typically interested in collaborating with external entities only in the specific areas in which they see a current or future need and in which they may be lacking in the requisite in-house expertise. Thus, in contrast to other Federal agencies that support relatively open-ended research, DOD laboratories seek collaborations in specific research areas and with a specific missionrelated goal in mind.

Many DOD laboratory leaders who provided input to this report stated that they were happy with the research partnership agreements that DOD laboratories have in place with universities (i.e., the larger and longer term collaborations such as CRADAs, CRAs, CTAs, and UARCs since these agreements fulfill their requirements. This view did not extend to personnel exchanges, educational partnerships, and other short-term agreements, which DOD-affiliated discussants for this study strongly endorsed and would like to see strengthened. From the perspective of "growing" the number of long-term and large-scale research partnership agreements between the two communities, this factor (i.e., DOD's satisfaction with the existing number of such partnership agreements) is an important consideration in a policy discussion.

University researchers, on the other hand, actively seek opportunities to engage collaboratively with DOD laboratories for reasons ranging from funding to participation in a technical partnership in which their research output could be applied to critical mission needs. However, STPI's discussions with leadership on both sides indicated that proposals for technical research collaborations submitted by universities do not get traction unless they match the specific research needs of DOD laboratories (as articulated in requests for information and broad agency announcements). Within this context, the implication seems to be that the onus is on the university to understand the laboratory's research needs and propose ideas for collaboration accordingly.

A second and related characteristic is that more emphasis seems to be placed on personal connections in collaborations with DOD laboratories than is the case with other funding agencies. One interviewee emphasized that the primary enabler of partnerships between Air Force laboratories and universities was the presence of personal connections 
between university principal investigators (PIs) and Air Force Research Laboratory researchers. In particular, former Air Force personnel who now serve as university researchers have been instrumental in forming new partnerships between the universities at which they currently work and the DOD laboratory from which they retired. Most of the Air Force's large-scale collaborations have begun through interactions facilitated by retired DOD personnel working at the university.

For the academic researcher, having established contacts within DOD laboratories or with DOD backgrounds translates into a better understanding of the current and future mission-oriented needs of DOD laboratories because of the restricted nature of some of the research. DOD laboratory and university officials who were interviewed agreed that new university professors who do not have connections with the DOD have difficulty breaking into DOD funding streams or connecting with DOD laboratories or researchers. These factors raise the concern that research collaborations between DOD laboratories and academia are not only incumbent on the laboratory's decision to seek out external expertise, but also, when initiated by the laboratory, can be dependent on individual contacts and the past practices of laboratories for securing the most appropriate resources. In short, DOD laboratory staff members may not be exposed to the full breadth of talent that exists in academia in their areas of need, which may, in turn, influence their decisions about reaching out to external experts. It may also prevent them from connecting to new faculty and younger researchers and from growing and broadening the talent pipeline that would benefit the future of the research enterprise.

On the other hand, physical proximity to a DOD laboratory was mentioned as allowing university and DOD laboratory researchers to forge deeper relationships. University discussants indicated that physical proximity to a laboratory allows collaborators more opportunities for face-to-face interaction and helps ensure that a project is well managed and that questions are answered iteratively throughout the project.

These overarching factors that influence the successful initiation of research collaborations between DOD laboratories and universities are presented at the outset to provide some of the conditions that have shaped research collaborations as they exist today. Much of the discussion that follows examines the collaborative partnership, with its attendant benefits and challenges. This document provides suggestions for policy actions that might overcome some of the challenges and result in expanding and deepening the landscape of research collaborations between DOD laboratories and academia. 


\section{Incentives and Benefits of Collaborating}

DOD laboratories have unique needs, capabilities, and facilities that contribute to the potential benefits of collaboration. As the research enterprise becomes more collaborative in nature, researchers in DOD laboratories and the universities are becoming increasingly aware of the benefits that research partnerships can offer.

In trying to understand how universities and DOD laboratories can collaborate better in the research enterprise, STPI researchers explored the motivations and incentives behind existing partnerships and the perceived benefits of these partnerships. Interviewees often viewed motivation and benefits interchangeably since prospective partnership benefits are also motivating factors. Appendix C provides the interview protocol used.

\section{A. Incentives for the DOD to Collaborate}

\section{Extending the Breadth and Depth of the DOD's Research Efforts}

At universities, the DOD can leverage broad-spectrum research capabilities to which it would otherwise not have access because of its mission-specific focuses, while simultaneously drawing from a pool of topical experts for its short-term needs.

\section{Providing Topical Area Expertise}

DOD laboratory research staff may sometimes have a need for specific topical area expertise in the short term and, as a result, reach out to university researchers to discuss DOD needs. This outreach develops relationships between the laboratories and universities and may lead to long-term collaborations.

A benefit of CRAs and CTAs, in particular, is that laboratory research staff obtain insight into external activity in the relevant research field, which allows for a more integrated approach to the research. For example, placing an Army problem in the university research environment provides an opportunity for the laboratory to get the best science across the facets of a complex issue and introduces new, interdisciplinary areas of research such as cyber-security and social sciences. Proximity plays a role in these partnerships because interviewees indicated that universities that were geographically closer to DOD laboratories and offices were more likely to be contacted for their expertise. 


\section{Leveraging University Facilities and Resources}

For government laboratories, the possibility of leveraging additional infrastructure and capabilities at the universities serves as an incentive for collaboration. While DOD laboratories have specialized resources and facilities necessary to fulfill their research missions, they sometimes lack the infrastructure or capabilities that are available to larger university programs.

The Air Force, for example, has a large number of collaborations motivated by the fact that its research laboratories lack some specialized capabilities that are available to university research facilities. Through a partnership with the University of Michigan, the Air Force has access to facilities for primate studies, which is a critical component for some of its research. Likewise, the University of Texas has an imaging center that was created through a UARC and is now available to the Air Force because of collaboration. In addition, through a CRADA, the University of Texas is applying for research funding for which the Air Force could not apply (which leverages funding and provides benefit to both the DOD and the larger public).

\section{Linking Federal and Third-Party Stakeholders}

Universities can serve as a flexible link between Federal laboratories and external research partners. Whereas the laboratories' and government agencies' funding grants are awarded through a competitive (sometimes lengthy) process, certain universities are structured so that they can reach out to third parties such as industry or Federally Funded Research and Development Centers (FFRDCs) without the having to go through competition or contracting. George Mason University has helped government laboratories speed up the research process and facilitate technology and intellectual property transition collaborations by quickly bringing outside parties together and linking them to FFRDCs, which can then link to government laboratories. For example, George Mason University has previously engaged with IDA's Systems and Analyses Center (an FFRDC) to work on commercial technology transfer issues for the DOD, the Department of State, and the Department of Commerce. This process works independently of laboratory structure and can be applicable across all DOD laboratories.

\section{B. Incentives for the Universities}

\section{Enhancing Academic Efforts of University Researchers}

University researchers can enhance their educational and research prospects by gaining access to DOD facilities, equipment, and institutional knowledge. Partnerships inspire talented researchers by exposing them to exciting mission-specific problems and transitioning their research outputs to applications in the field. From the DOD's perspective, a university researcher who is familiar with DOD-university collaborations 
improves the collaborative quality of the educational institution. In an adverse funding climate, university researchers see the DOD as an encouraging potential source of funding.

\section{Providing Access to Specialized Facilities at DOD Laboratories}

Many of the university interviewees indicated that collaborating with DOD laboratories allows them access to specialized facilities that universities may not be able to afford or may not be permitted to develop, while allowing Federal laboratory partners to employ academic talent to solve crucial problems. In particular, researchers in the chemical, biological, radiological, nuclear, and explosives fields benefit from having access to spaces where they can handle pathogens and other hazardous biological and chemical substances, which are outside the scope of what most university permits allow.

\section{Partnering with the DOD in a Collaborative Environment}

University interviewees indicated that the DOD funding environment allows for a different type of interaction than is normally expected of agencies such as the National Science Foundation (NSF) and the National Institutes of Health (NIH). NSF and NIH offer funds but have limited interaction with the university investigators, the DOD offers opportunities for more interactive research partnerships. Additionally, universities can send researchers, students, and post-doctoral researchers to work in DOD laboratories through Intergovernmental Personnel Act (IPA) assignments and student fellowships and agreements, with the potential to create and grow a talent pipeline in specialized S\&T skills.

\section{Providing Opportunities for Students}

Research partnerships can also provide exciting employment opportunities for university students interested in honing their talents and probing new and exciting scientific challenges. Students involved in collaborative projects might find potential access to a summer or post-graduate research position at DOD laboratories. Students learn about research that is important to the DOD, and university-industry collaborations are a great way to develop a pipeline of students for defense-related research. Accordingly, universities and laboratories may find mutual benefits from involving students in collaborative research projects. Universities benefit by helping to secure research positions for their graduates, and the laboratories benefit by increasing their exposure to the universities' top-level research talent.

\section{Joint Incentives}

\section{Faculty and Student Exchange: Building a Talent Pipeline}

Many interviewees agreed that personnel exchanges between DOD and university researchers, post-doctoral researchers, and students were crucial in building awareness of 
DOD research needs and culture and establishing long-term connections that forge future collaborative relationships.

During sabbaticals or through mechanisms such as IPA agreements, faculty have the opportunity to conduct research at DOD laboratory facilities and, in many cases, can further their own research. Student exchanges were specifically mentioned in this context. Training programs and internships are excellent ways for the research community at Federal laboratories to interact with students and develop and grow a talent pipeline for DOD research needs.

Some specific programs include the Air Force Summer Faculty Fellowship Program (SFFP), ${ }^{4}$ the United States Air Force/National Research Council - Resident Research Associateship (USAF/NRC-RRA) Program, ${ }^{5}$ the Naval Research Sabbatical Leave Program $^{6}$ for faculty, and the College Qualified Leaders (CQL) ${ }^{7}$ program for undergraduate students, graduate students, and post-doctoral researchers.

DOD interviewees remarked that while some efforts have been made to track student movement to DOD laboratories, no standard processes were in place to document current and previous student and faculty exchanges in DOD laboratories.

\section{Technology Transfer}

The mission-based focus on applied research and development (R\&D) at DOD laboratories creates a supply side "pull” for many areas of basic research conducted at universities. In this context, universities and the laboratories play complementary roles because universities are biased towards basic research and DOD laboratories (which also conduct basic research) operate in the realm of translating the research output into missionrelevant applications.

4 See U.S. Air Force website, “Summer Faculty Fellowship Program (SFFP),” last accessed March 10, 2013, http://sffp.asee.org/.

5 See Wright-Patterson Air Force Base website, “AFOSR: United States Air Force /National Research Council - Resident Research Associateship (USAF/NRC-RRA) Program,” last accessed March 10, 2013, http://www.wpafb.af.mil/library/factsheets/factsheet.asp?id=9378.

6 See the Office of Naval Research website, "Summer Faculty Research Program and Sabbatical Leave Program,” last accessed March 10, http://www.onr.navy.mil/Education-Outreach/Summer-FacultyResearch-Sabbatical.aspx.

7 See U. S. Army website, “CQL Program - College Qualified Leaders,” last accessed March 10, 2013, http://www.usaeop.com/programs/CQL/. 


\section{Publications}

While university officials interviewed voiced concerns about student publications for projects falling under International Traffic in Arms Regulations (ITAR) ${ }^{8}$ or other publication restrictions, research that produces joint publications with DOD laboratories would be beneficial.

8 ITAR implements the Arms Export Control Act (AECA), which governs the export and temporary import of defense articles and services. 



\section{Overcoming Challenges and Leveraging Other Considerations Regarding DOD Laboratory and University Research Collaborations}

While collaborations between DOD laboratories and universities have many valuable benefits, some unique aspects of DOD Federal laboratories and Federal entities can create challenges for initiating, developing, and maintaining these partnerships. Universities in particular may face or perceive these challenges because they may lack complete information on how to resolve or navigate them. Beyond these challenges, there are also considerations related to personal connections and proximity that universities should be aware of if they are to engage successfully with DOD.

This section describes the challenges and other considerations that dictate how and when collaborative partnerships are usually initiated (echoing the issues articulated in Chapter 3), as well as the issues that become relevant once the need for such a partnership has been determined. All of these challenges and other considerations should be kept in mind when attempting to identify strategies to facilitate university and DOD laboratory collaborations.

Several of the interviewees, both from the universities and DOD, had recommendations for mitigating existing challenges and cultivating new or existing collaborative partnerships in light of the nature of working with the DOD. While DOD laboratory leadership who were interviewed for this task generally expressed satisfaction with the level and status of academic research collaborations that currently exist, most interviewees felt that improving awareness and outreach could provide great benefit in helping to reduce barriers and inspire new successes. The recommendations gleaned from the interviewees' insights are distilled into the suggestions articulated in this chapter.

\section{A. Challenges to Initiating Collaborations}

\section{Lack of Awareness of and Misconceptions about the DOD by Universities}

Awareness and familiarity can be critical factors in successful collaborations because these attributes can help provide external researchers some knowledge of the circumstances surrounding DOD research. According to one university official, new academic researchers typically know about research funding from agencies such as NSF, DOE, 
and NIH, but there is a general lack of awareness and information in the academic community about DOD-funded research and the rules governing collaboration with DOD researchers. Even those who do know might have trouble finding DOD research projects and knowing how to initiate these partnerships without an understanding of DOD practices and culture. This lack of awareness is particularly acute for young researchers or those with no previous experience with the DOD. The perception is that veteran researchers know about the particular mechanisms that exist for working with DOD and have learned how to present their work, integrate with the culture, accommodate the restrictions, and navigate other issues, while less seasoned researchers feel deterred from seeking out new collaborations.

Additionally, university researchers often have misconceptions about the research restrictions or security protocol inherent to working with the DOD and unclear understandings of how these would apply to them. One example of this is the misconception among some academics that the bulk of DOD’s R\&D efforts are classified. In reality only a fraction of the research is classified. In addition, while Federal export control regulations can restrict the publication of defense-related research, it allows exceptions for basic research, a fact that university researchers may not know.

Misconceptions also exist in the assignment of intellectual property (IP) resulting from university research collaborations with DOD laboratories. An illustrative example is the concern of would-be collaborators over government march-in rights, which establish the government's ability to reassign IP in a case in which a non-Federal party does not commercialize a technology that is imperative to the public welfare of the United States. This right can only be used in cases where (1) the non-Federal partner is assigned a license to IP but does not seek to commercialize it within a reasonable time and (2) the commercialization of the IP is deemed necessary to public health and safety needs of the country.

Although march-in rights have, to date, never been used to take IP away from a nonFederal party, universities are often reluctant to initiate any form of collaboration that could allow another entity to take away their IP or force them to license their technology, and this hesitation can be a barrier to collaborative efforts.

Recommendation: Both DOD laboratories and universities should promote awareness by increasing outreach activities

DOD laboratories and universities are encouraged to consider more outreach activities that would allow potential research partners to learn about DOD work and allow DOD to identify potential collaborators. Outreach would also provide the academic community insight into the DOD's operating procedures and structure. Structured outreach activities, such as universities inviting DOD laboratory researchers to present their research 
(and vice versa), have been successful in allowing researchers from both communities to identify common research interests and to build mutual familiarity. University researchers noted that industry groups often hold such outreach events on their campus and that these events are a cost-effective ways to make connections. Interviewees also expressed that it is often difficult for individual researchers to approach the laboratories and that having university, laboratory, and industry colloquia would help all parties learn of opportunities to collaborate. Even activities such as inviting university researchers to give talks at DOD laboratories are helpful.

\section{Recommendation: DOD laboratories should consider providing guidance to outsiders on context and "rules of the road" for collaboration}

Interviewees from both the DOD and the academic community emphasized that the perceived barriers to collaboration were usually problems that could be solved by educating the academic community on ways to connect with DOD laboratories. Accordingly, one policy recommendation is for DOD laboratories to provide greater clarity to the academic community on "rules of the road" for collaborating with the DOD, as well as increase awareness and publicity of DOD funding announcements for universities to explore collaborations in areas which match their areas of expertise.

DOD is different from other agencies vis-à-vis exploring research opportunities in that DOD laboratories typically seek collaborations only in the focused areas defined by their mission needs. Universities are urged to view the DOD as the customer who will ultimately determine the areas in which he or she will seek collaborations. Consequently, rather than proposing collaboration in their areas of interest, universities should meet with DOD researchers or find other ways to familiarize themselves with the DOD's areas of need when looking for collaboration opportunities.

\section{Classification or Security Restrictions May Impede Collaboration}

As might be expected, DOD research projects are likely to be associated with security precautions, including a series of restrictions and regulations on facilities, personnel, and IP involved in DOD research, which are enforced to protect national interests. Although the large majority of DOD research conducted in collaboration with academia is likely to be unclassified, classification requirements can still hinder development of a research partnership.

For example, ITAR may restrict foreign nationals and international partners from working on specific types of projects. This restriction can be an issue for collaboration when the university has a strong international population of researchers. Many universities also identified this restriction as a barrier because faculty who work with international 
partners or foreign nationals working in their laboratories may be reluctant to accept or seek research that isolates their colleagues.

Such classification requirements or security restrictions may lead to a delay of the partnership-initiation process due to security clearances and complex negotiations of the collaborative contracts. Results of a 2012 Faculty Workload Survey conducted by the Federal Demonstration Partnership show that faculty who conduct research related to national security ace a higher administrative burden than those who do not. ${ }^{9}$ While many universities try to find ways to comply with security requirements, the potential restrictions and administrative burdens associated with classified research can limit the pool of universities and researchers who are able and willing to collaborate, and they can cause universities to back out of collaborative partnerships.

Recommendation: DOD laboratories should clarify security requirements when establishing their agreements and provide pathways to resolve issues when possible

For security-related issues (e.g., obtaining clearance for foreign nationals) that involve considerable overhead from the perspective of the academic research collaborator, DOD laboratories should provide clear paths for resolving issues and increase university researchers' understanding of the motivation for certain restrictions were cited as possible policy solutions to this problem.

An additional suggestion was for DOD laboratories to explore the possibility of creating separate spaces at their facilities specifically designated for unclassified work. For example, the DOE's Lawrence Livermore National Laboratory and Sandia National Laboratories have come together to create the Livermore Valley Open Campus, an open access space to allow for collaboration with academia and industry. This "outside the fence" model could allow some DOD laboratories increased flexibility in forming new collaborations for unclassified basic research.

\section{Perception of Legal, Ethical, or Security Restrictions by Would-be Collaborators at DOD Laboratories}

As a Federal entity, the DOD has certain legal and ethical liabilities (e.g., conflicts of interest [COIs], U.S. manufacturing preferences, tort law, and indemnity regulations) that may complicate collaborative research partnerships. These regulations can be transferred to those organizations that work with the DOD or accept DOD funding, depending on the context of the partnership. This transfer of liabilities tends to make DOD researchers cautious about their research partners and the content of the partnership contracts.

9 Results of the 2012 Faculty Workload Survey, presented at the Federal Demonstration Partnership meeting, January 2013, Washington DC, http://sites.nationalacademies.org/PGA/fdp/PGA_081164. 
Universities, on the other hand, can become wary of the DOD's cautious approach and its reluctance to negotiate.

DOD officials identified navigating the DOD's joint ethics or COI regulations as a significant hurdle to overcome in partnering with non-Federal entities. DOD laboratories must be cognizant of receiving outside compensation-even one as seemingly innocuous as a university flying a DOD researcher to a site visit—because it can be considered illegal. The DOD and its partners must comply with criminal statutes on COIs (18 U.S.C. §§ 208209), which prevent partners from participating in matters that can predictably affect their financial interest or the financial interest that will be imputed to them. The DOD's other ethical concerns include receiving gifts from prohibited sources, working with impartiality, and distributing procurement solicitations and endorsements fairly.

Lack of clarity on whether the Federal Acquisition Regulation (FAR) applies to research collaborations with academia is another challenge to negotiating DOD-university partnerships. DOD officials noted that Federal research managers are cautious about the constraints and liabilities of FAR agreements, ${ }^{10}$ which form an impediment to the research collaborations governed, or perceived to be governed, by the FAR.

\section{Recommendation: DOD laboratories need to provide clarity on DOD-specific regulations and restrictions}

Laboratories could provide guidance to their researchers about potential COIs and other topics relevant to engaging with outside researchers so as to address misconceptions on both sides before negotiating collaboration agreements. Furthermore, DOD guidance could help clarify for university researchers that basic research programs are not subject to FAR requirements.

The intricacy of rules and restrictions related to the FAR can often confuse and deter researchers - particularly those who are unfamiliar with the DOD in terms of context and culture-from seeking collaboration (even though research projects are not subject to all of the same rules as acquisition). DOD officials believe that an effort to educate people (internally and externally) has to be undertaken to ensure that these people know how the DOD and Federal regulations in general-but the FAR and ITAR in particular-apply to collaborative agreements.

\footnotetext{
${ }^{10}$ For example, regulations for using Federal funds for transportation and conferences are stricter for FAR contracts than for most research and assistance agreements, but the distinctions between the two are not clear. This confusion could result in Federal researchers worrying about whether FAR rules are being broken and university researchers being harnessed with restrictive regulations that may not apply to them.
} 


\section{General Uncertainty about Funding Arrangements}

Lack of clarity on funding mechanisms and the associated restrictions with respect to different partnership agreements can hinder contract negotiations, particularly in cases when both parties contribute to the project funding. Under certain contract types, such as CRADAs, the financial burden is primarily borne by the university. In other cases, the DOD can be the primary funder (e.g., through UARC agreements). Uncertainty over the restrictions on when the DOD can contribute funding can dissuade some universities from being willing to enter into an agreement.

Even when funding can be delineated, a DOD official noted that the party that provides funds can shape the direction of the research. This issue can be a problem when, for example, one institution provides funding for 6.2 (applied) research and another provides funding for 6.1 (basic) research. This dual-funding approach can instigate disagreements over the content of the research. But making sure that issues such as these are openly discussed, negotiated, and agreed upon before drafting statements of work and contracts can save time and avert frustration for both partners.

Contract negotiations between university researchers and a DOD laboratory are sometimes delayed or even terminated because the researchers-from the Federal laboratories and the universities - do not have an understanding of the restrictions and requirements that might apply to the research area under discussion. Sometimes, this situation arises from a lack of guidelines that differentiate what constitutes fundamental research and what constitutes research that is required to comply with export controls. The additional requirements for classified research, such as the need for secure facilities and the personnel restrictions, can hamper the university's efforts because it is unable to comply. Some universities have asked their DOD sponsors to extract parts of the research that can be publically released and that their students can publish, but this request has not always been easy or possible to implement.

The lack of transparency and unavailability of information to university officials may sometimes result in contract negotiations coming to a stop when the terms are being reviewed by the business office, which occurs after the researchers have come to an agreement on the work. DOD laboratory officials and the university officials noted a lack of information and communication that cannot only curtail or terminate collaborative efforts, but can also make the idea of collaboration unappealing.

\section{Recommendation: DOD laboratories can create memorandums of understanding (MOUs) or collaborative consortiums with university partners to clarify contract uncertainty}

Interviewees pointed out that formalized but general agreements often help to pave the way for future collaboration and help clarify funding responsibility and available collaborative mechanisms. One suggested approach was for laboratories and universities 
to sign blanket MOUs that provide the legal foundation for collaborative projects. While MOUs are relatively open-ended, interviewees largely saw them as having a tremendous enabling effect on removing legal barriers and fostering collaborative relationships. Such agreements provide flexibility for a variety of interactions with the university partner and can be signed at the research program, laboratory, or agency level.

Expanding existing mechanisms, such as CRAs and CTAs, could enable collaboration through university consortia designed to support DOD laboratory research. Such alliances would have the flexibility to connect the laboratories and FFRDCs to university and industry researchers. Laboratories, by expanding their interaction with university consortia, may be able to leverage partnerships that meet their collaborative research needs.

\section{Increased Patent Filing Fees when Partnering with Government Entities \\ Patent filing fees for universities can increase when partnering with Federal agencies because universities lose their micro-entity status as provided for in the} America Invents Act. By virtue of the provisions in the America Invents Act (35 U.S.C. § 123), universities are eligible for "micro-entity" status when filing for patents, which can result in a maximum 75\% reduction of their patent filing fees. However, any IP produced in a joint involvement with an organization that is not entitled to micro-entity status could not be filed using the reduced fees - a stipulation that a DOD official pointed out as effectively providing a financial disincentive for universities to collaborate with U.S. Government partners.

In addition, if a university inadvertently did apply for micro-entity status for IP from a partnership with the government, it might risk having its patents held up, denied, or invalidated for infringement. This risk provides an additional wariness to non-Federal partners who might want to initiate a collaborative research partnership with the Federal Government.

But working with the U.S. Government has its benefits. The terms of the Bayh-Dole ${ }^{11}$ and Stevenson-Wydler Acts ${ }^{12}$ specify that government entities must allow non-Federal

11 The Bayh-Dole Act of 1980 was enacted as a measure to revive the U.S. economy, as U.S. international competitiveness was waning after World War II. Bayh-Dole was aimed at increasing technology transfer and enabled Federal agencies and government-owned, government operated (GOGO) laboratories to issue exclusive licenses to government-held patents. Previously, only non-exclusive or open licenses could be granted. Further amendments allowed government-owned, contractor-operated (GOCO) laboratories and private companies to obtain an exclusive license for the whole life of the government patent.

12 The Stevenson-Wydler Technology Innovation Act of 1980 was the first major piece of legislation that encouraged technology transfer, personnel exchange, and joint research between the Federal laboratories, industry, and State and local governments. The law specified that each Federal laboratory with 200 or more technical staff had to establish a technology transfer office, referred to as the Office of 
partners such as universities to assume the title of IP generated under certain funding agreements or collaborative research programs. These benefits, though, are tied to IP regulations and restrictions inherent with all government projects.

\section{Recommendation: The DOD should consider proposing legislation to avoid increased patent filing fees}

The issue of increased patent filing fees for DOD collaborators is being considered by the Interagency Working Group on Technology Transfer (IAWGTT), which commented on the potential negative effects of collaboration between Federal and university researchers. In December 2012, the U.S. Patent Office responded to this comment by noting that the application of micro-entity status was constrained by classifications established in the Higher Education Act of 1965. Removing this barrier may require legislative action to amend the America Invents Act or previous legislation such as the Higher Education Act ${ }^{13}$ to exempt institutions that collaborate with Federal government laboratories from losing their micro-entity status. According to one interviewee, the IAWGTT is currently developing legislation that could be used to address this problem.

\section{B. Other Considerations for Enhanced Collaboration Opportunities}

\section{Need for Personal Connections}

As mentioned previously, establishing personal contacts and connecting with the right people appear to be prerequisites when establishing collaborations with DOD scientists. Personal contacts are important to discovering what research at DOD laboratories might be of interest to university faculty. This contact also gives external researchers some knowledge of the regulations and restrictions imposed on DOD research. This approach is different from the funding processes of traditional sources of R\&D funding (e.g., NSF and $\mathrm{NIH}$ ), where a previously unfunded researcher may have a greater chance of winning a grant award.

When university research directors talk to researchers who have started programs with the DOD, they are surprised by how many of these programs were developed because of personal relationships. Listed below are four recommendations to enhance personal connections.

\footnotetext{
Research and Technology Applications (ORTA). Congress has since passed many pieces of legislation aimed at increasing the societal impact of Federal laboratory research through technology transfer.

13 Title 35 U.S.C. § 123 and Title 20 U.S.C. § 1001(a).
} 
Recommendation: The DOD should consider expanding personnel exchange programs between laboratory and university researchers

Personnel exchanges between laboratory and university researchers were consistently cited as a way to heighten awareness of the DOD research enterprise and to build collaborative relationships. Currently, DOD research laboratories can hire university researchers who are on sabbatical to work for the laboratory on a temporary basis. This hiring can occur through a Single Investigator, a Multidisciplinary University Initiative (MURI), a CRA or CTA, or an IPA assignment. Conversely, laboratory researchers or extramural funding program managers (PMs) can also retain joint appointments (which include formalized processes for managing COIs) with universities. Continuing to encourage and expand these types of exchanges is one way to strengthen the relationships between universities and the laboratories. University interviewees indicated their interest in increased opportunities to develop these types of personnel exchanges.

Relatedly, the increased use of rotating scientists as laboratory or extramural funding PMs could help bolster the laboratories' motivation to collaborate. Interviewees cited the high prevalence of rotating PMs in institutions such as NSF and managers originating from university positions as a beneficial way of increasing knowledge of the research environment and building widespread connections with researchers in academia. While the DOD's extramural funders also use the IPA mechanism to bring in PMs from universities, this mechanism did not appear to be used as extensively as in agencies such as NSF. One interviewee cautioned that having too many rotators would reduce the institutional memory of the granting agency. Nevertheless, a policy suggestion is to consider increasing the number of rotating PMs who come from university positions and are placed in the funding offices and the laboratories since doing so could further the DOD research enterprise's connection to academia.

Recommendation: DOD laboratories should consider expanding support for firsttime researchers

DOD laboratories should consider expanding existing seed grant programs for first-time researchers or universities that have never previously worked with the DOD to increase the DOD's visibility in newer communities and provide access to fresh talent. These grants could be relatively modest in amount but would target young investigators who do not have previous DOD experience working with the DOD, but are potential new collaborators. A university interviewee argued that a similar program at NIH has helped that agency build its reputation among newly established researchers, and the resultant publicity in the "new researcher community" has allowed the program to grow rapidly.

Since several of the extramural funding entities in the DOD already operate "Young Investigator" programs, the interviewees suggested expanding these programs or 
increasing awareness of programs that focus specifically on researchers who have not had previous DOD experience.

Recommendation: DOD laboratories should consider expanding student programs and post-doctoral fellowships

DOD laboratories currently organize a wide range of programs for students, including tuition assistance for researchers who are completing advanced degrees and opportunities for graduate students to work temporarily in a laboratory. These programs are largely viewed as being successful, and interviewees recommended that expanding them might help to increase the personal connections that lead to laboratory-university collaboration.

DOD laboratories should consider taking steps to strengthen and expand postdoctoral fellowship programs at the laboratories. Post-doctoral fellowships were described as effective ways to bring research talent to the laboratories to the laboratories at a relatively low cost and to attract recent graduates who have connections to the academic community. These young researchers can serve as a bridge between laboratory and university research, which could ultimately transition into broader-scale collaborations. Interviewees noted that this early exposure was a common theme among university researchers who frequently collaborate with DOD laboratories.

The post-doctoral fellowship at the National Institute of Standards and Technology (NIST) was cited as a successful attempt to recruit talented young researchers and to increase collaboration between the university and the laboratory. While the laboratories do set aside some funds for post-doctoral fellowships, interviewees claimed that the rules governing the programs were not formalized, which sometimes makes the recruitment process challenging. Accordingly, formalizing and allocating funds to post-doctoral fellowships is one policy suggestion for increasing visibility and attracting young talent.

\section{Recommendation: Reduce restrictions for DOD researchers to attend conferences}

A number of interviewees suggested that the current limitations on allowing DOD laboratory researchers to attend and present at conferences were negatively affecting DOD laboratories' collective ability to create personal connections in academia. Accordingly, one policy suggestion is for the DOD to review, clarify, and potentially reduce the limitations on conference travel to ensure an appropriate level of mobility for laboratory researchers seeking to connect with the academic community.

\section{Value of Physical Location and Proximity}

Both DOD laboratory and university officials identified location and spatial separation as a potential barrier to collaboration, particularly in light of travel and other 
budget restrictions. For example, faculty at the University of Maryland, College Park, less than 10 minutes from the Army Research Laboratory (ARL), enjoy a strong relationship with researchers at ARL. Federal laboratories in more remote locations are at a disadvantage when it comes to offering faculty exchange or IPA assignments since senior researchers may be reluctant to move themselves or their families to these places.

\section{Recommendation: Consider distance in collaborative relationships and offset through other mechanisms}

Interviewees largely agreed that increasing proximity was, for the most part, not an effective measure to consider for increasing collaboration. Accordingly, laboratories or universities seeking to build collaboration with a more distant partner might consider incentives for travel or relocation for the duration of their partnerships or personnel exchanges. While some universities or Federal laboratories have been able to move or build satellite campuses near would-be collaborators, distance between a university and a laboratory did not preclude collaboration. In fact, such factors as strong personal connections were seen as potential ways to mitigate the effect of distance on the likelihood of collaborating. 



\section{Summary of Challenges and Recommendations}

Table 2 summarizes barriers to the OSTP's goal of expanding and streamlining collaborative research partnerships between DOD laboratories and universities. It also provides recommended policy solutions to overcome them.

Table 2. Suggested Policy Actions to Alleviate Challenges and Other Considerations that Hinder DOD-Academic Collaborative Research Partnerships

\begin{tabular}{|c|c|c|}
\hline Section & Challenges/Considerations & Recommendations \\
\hline \multirow[t]{3}{*}{ 5.A.1 } & $\begin{array}{l}\text { Researchers in academia may lack awareness } \\
\text { about the structure, mission, research expertise, } \\
\text { and facilities of DOD laboratories, and often are } \\
\text { not fully aware of the research activities, } \\
\text { collaboration opportunities, and funding } \\
\text { mechanisms provided through the laboratories. }\end{array}$ & $\begin{array}{l}\text { DOD laboratories and universities should } \\
\text { increase outreach events, particularly those } \\
\text { including targeted, research-based } \\
\text { discussions between laboratory staff and } \\
\text { faculty. }\end{array}$ \\
\hline & $\begin{array}{l}\text { Non-Federal collaborators may believe that } \\
\text { security limitations or proprietary intellectual } \\
\text { property restrictions would make collaboration } \\
\text { impossible or undesirable. }\end{array}$ & $\begin{array}{l}\text { DOD laboratories should provide greater } \\
\text { clarity to the academic community on "rules } \\
\text { of the road" for collaborating with the DOD } \\
\text { and with specific laboratories. }\end{array}$ \\
\hline & $\begin{array}{l}\text { The DOD is generally able to engage only in } \\
\text { research collaboration pertinent to specific } \\
\text { topics, usually specified in DOD research } \\
\text { funding announcements }\end{array}$ & $\begin{array}{l}\text { DOD laboratories should increase } \\
\text { awareness and publicity of funding } \\
\text { announcements, and encourage } \\
\text { universities to consider engaging in } \\
\text { collaborations where their research } \\
\text { overlaps with a DOD funding opportunity. }\end{array}$ \\
\hline \multirow[t]{2}{*}{ 5.A.2 } & $\begin{array}{l}\text { Classification or security restrictions may impede } \\
\text { collaboration (e.g., research may not be } \\
\text { publishable, or foreign students may be } \\
\text { restricted from working in laboratories). }\end{array}$ & $\begin{array}{l}\text { DOD laboratories should develop clear } \\
\text { paths for resolving issues and increase } \\
\text { university researchers' understanding of the } \\
\text { motivation for certain restrictions. }\end{array}$ \\
\hline & & $\begin{array}{l}\text { DOD laboratories should explore creating } \\
\text { partitioned, unclassified work spaces to } \\
\text { facilitate collaboration. }\end{array}$ \\
\hline 5.A.3 & $\begin{array}{l}\text { The perception of legal, ethical, or security } \\
\text { restrictions by would-be collaborators at DOD } \\
\text { laboratories dissuades them from seeking } \\
\text { external partnerships. }\end{array}$ & $\begin{array}{l}\text { The DOD and its laboratories should provide } \\
\text { guidance to their researchers about } \\
\text { engaging with outside researchers, and } \\
\text { additional DOD memos citing existing Office } \\
\text { of Management and Budget (OMB) circulars } \\
\text { could also help to delineate restrictions on a } \\
\text { number of topics as they apply to research } \\
\text { programs. }\end{array}$ \\
\hline \multirow[t]{2}{*}{ 5.A.4 } & $\begin{array}{l}\text { Lack of a framework or a general agreement } \\
\text { providing for collaboration can serve as a } \\
\text { hindrance to starting new research cooperation. }\end{array}$ & $\begin{array}{l}\text { DOD laboratories and universities should } \\
\text { seek out Memoranda of Understanding so } \\
\text { as to clarify the bounds of collaborative } \\
\text { relationships and enable future work. }\end{array}$ \\
\hline & $\begin{array}{l}\text { Funding contributions from the Federal } \\
\text { Government vary depending on the type of }\end{array}$ & \\
\hline
\end{tabular}




\begin{tabular}{|c|c|c|}
\hline Section & Challenges/Considerations & Recommendations \\
\hline & $\begin{array}{l}\text { collaborative agreement, and resolving } \\
\text { differences in research interests between two or } \\
\text { more funding parties can be challenging. }\end{array}$ & $\begin{array}{l}\text { Both parties should also ensure that funding } \\
\text { issues and research directions are openly } \\
\text { discussed, negotiated, and agreed upon } \\
\text { before drafting a collaborative contract. }\end{array}$ \\
\hline 5.A.5 & $\begin{array}{l}\text { Universities partnering with Federal agencies } \\
\text { lose their micro-entity status for filing patents (as } \\
\text { created in the America Invents Act), resulting in } \\
\text { greatly increased fees. }\end{array}$ & $\begin{array}{l}\text { DOD laboratories and universities should } \\
\text { consider proposing a legislative solution to } \\
\text { the issue of patent filing fees through the } \\
\text { Interagency Working Group on Technology } \\
\text { Transfer. }\end{array}$ \\
\hline \multirow[t]{3}{*}{ 5.B.1 } & $\begin{array}{l}\text { Personal connections are important to strong } \\
\text { collaborations and non-Federal researchers who } \\
\text { have never collaborated with the DOD or lack } \\
\text { personal connections to laboratory researchers } \\
\text { can find it difficult to make inroads to } \\
\text { collaboration with the DOD. }\end{array}$ & $\begin{array}{l}\text { DOD laboratories and universities should } \\
\text { consider expanding personnel exchanges. } \\
\text { The DOD and its laboratories should } \\
\text { consider expanding support for existing seed } \\
\text { grant programs for first time researchers or } \\
\text { universities who have never previously } \\
\text { worked with the DOD. }\end{array}$ \\
\hline & & $\begin{array}{l}\text { DOD laboratories should consider } \\
\text { expanding student programs and post- } \\
\text { doctoral fellowships. }\end{array}$ \\
\hline & & $\begin{array}{l}\text { The DOD should clarify rules for sending } \\
\text { laboratory researchers to conferences, and } \\
\text { DOD laboratories should prioritize doing so } \\
\text { when possible so researchers can make } \\
\text { connections and present their work. }\end{array}$ \\
\hline 5.B.2 & $\begin{array}{l}\text { A lack of physical proximity between laboratories } \\
\text { and universities may impede effective } \\
\text { collaboration. }\end{array}$ & $\begin{array}{l}\text { DOD laboratories and universities might } \\
\text { work to offset distance with other } \\
\text { mechanisms (e.g., encouraging personal } \\
\text { connections, providing incentives for travel } \\
\text { or relocation in collaborative relationships or } \\
\text { personnel exchanges). }\end{array}$ \\
\hline
\end{tabular}




\section{Appendix A. List of Interviewees}

Table A-1. Names and Affiliations of DOD Interviewees

\begin{tabular}{|c|c|c|}
\hline Organization & Name & Title \\
\hline \multirow[t]{2}{*}{$\begin{array}{l}\text { Office of Secretary of Defense } \\
\text { (OSD) }\end{array}$} & Appler, David & $\begin{array}{l}\text { Office of Research and Technology } \\
\text { Applications (ORTA)/Technology Transfer }\end{array}$ \\
\hline & Fischer, John & $\begin{array}{l}\text { Office of the Assistant Secretary of Defense for } \\
\text { Research and Engineering/Director, } \\
\text { Laboratories }\end{array}$ \\
\hline Army & Adams, Bill & $\begin{array}{l}\text { Associate Deputy General Counsel } \\
\text { (Acquisition) }\end{array}$ \\
\hline $\begin{array}{l}\text { Army Research, Development } \\
\text { and Engineering Command } \\
\text { (ARDEC) }\end{array}$ & $\begin{array}{l}\text { Beauchamp, } \\
\text { Edward }\end{array}$ & Legal Office \\
\hline $\begin{array}{l}\text { Army/Assistant Secretary of the } \\
\text { Army, Acquisition, Logistics, and } \\
\text { Technology (ALT) }\end{array}$ & Singleton, Jeffrey & $\begin{array}{l}\text { Director for Basic Research, Laboratory } \\
\text { Management and Educational Outreach for the } \\
\text { Assistant Secretary of the Army (ALT) }\end{array}$ \\
\hline \multirow[t]{3}{*}{ Army Research Office (ARO) } & Skatrud, David & $\begin{array}{l}\text { Director ARO and Deputy Director, Basic } \\
\text { Science, ARO }\end{array}$ \\
\hline & Lee, Stephen & Chief Scientist \\
\hline & Becker, Jennifer & Reactive Chemical Systems Program Manager \\
\hline Army Research Laboratory (ARL) & Pellegrino, John & $\begin{array}{l}\text { Director, Computation and Information } \\
\text { Sciences Directorate }\end{array}$ \\
\hline Office of Naval Research (ONR) & Schuette, Lawrence & Director of Innovation at ONR \\
\hline $\begin{array}{l}\text { Naval Surface Warfare Center } \\
\text { (NSWC) Crane Division }\end{array}$ & Dement, John & ORTA/Technology Transfer \\
\hline NSWC Crane Division & Acton, Dave & ORTA/Technology Transfer \\
\hline Air Force Medical Service & Sharon, Danny & Research Officer \\
\hline $\begin{array}{l}\text { Air Force Office of Scientific } \\
\text { Research (AFOSR) }\end{array}$ & Carrick, Patrick & Director of the Basic Science Program Office \\
\hline National Academies & Jaggers, Terry & Director, Air Force Studies Board \\
\hline
\end{tabular}


Table A-2. Names and Affiliations of University Interviewees

\begin{tabular}{|c|c|c|}
\hline University & Name & Title \\
\hline Duke University & Siedow, James & Vice Provost for Research \\
\hline \multirow[t]{3}{*}{ George Mason University } & Bolognese, Kerry & Director of Federal Relations \\
\hline & Gabriel, Kenneth & $\begin{array}{l}\text { Assistant Vice President for Translational } \\
\text { Research }\end{array}$ \\
\hline & McBride, Dennis & $\begin{array}{l}\text { Associate Vice President for Research and } \\
\text { Economic Development }\end{array}$ \\
\hline \multirow[t]{2}{*}{ George Washington University } & Korman, Can & $\begin{array}{l}\text { Associate Dean for Research and Graduate } \\
\text { Studies }\end{array}$ \\
\hline & Schulz, Geralyn & Associate Dean for Research \\
\hline $\begin{array}{l}\text { Georgia Institute of Technology } \\
\text { (Georgia Tech) }\end{array}$ & Cross, Stephen & Executive Vice President for Research (EVPR) \\
\hline Georgetown University & Dimolitsas, Spiros & $\begin{array}{l}\text { Senior Vice President for Research and Chief } \\
\text { Technology Officer }\end{array}$ \\
\hline Rensselaer Polytechnic Institute & Dordick, Jonathan & $\begin{array}{l}\text { Vice President for Research, Department of } \\
\text { Chemical and Biological Engineering, Center } \\
\text { for Biotechnology and Interdisciplinary Studies }\end{array}$ \\
\hline University of Kansas & Warren, Steven & $\begin{array}{l}\text { Vice Chancellor for Research and Graduate } \\
\text { Studies }\end{array}$ \\
\hline \multirow[t]{3}{*}{ University of Maryland } & Gertz, Kenneth & $\begin{array}{l}\text { Associate Vice President for Research } \\
\text { Development }\end{array}$ \\
\hline & Grad, Rae & $\begin{array}{l}\text { Assistant to the President/ Director of Federal } \\
\text { Relations }\end{array}$ \\
\hline & O'Shea, Patrick & Vice President and Chief Research Officer \\
\hline University of Virginia & Bienvenue, Joan & Director, Applied Research Institute \\
\hline \multirow{3}{*}{$\begin{array}{l}\text { Virginia Polytechnic Institute and } \\
\text { State University } \\
\text { (Virginia Tech) }\end{array}$} & $\begin{array}{l}\text { Yianilos, } \\
\text { Christopher }\end{array}$ & Director of Federal Government Relations \\
\hline & Bohland, James & $\begin{array}{l}\text { Executive Director for National Capital Region } \\
\text { Operations }\end{array}$ \\
\hline & Raman, Sanjay & Associate Vice President \\
\hline
\end{tabular}




\section{Appendix B. \\ Examples of Laboratory-University Interactions}

Table B-1. Examples from Interviewees of Interactions between Laboratories and Universities

\begin{tabular}{|c|c|c|c|c|c|}
\hline $\begin{array}{l}\text { DOD } \\
\text { Laboratory }\end{array}$ & University Partner(s) & Name of Initiative & Mechanism & Research Area & Duration \\
\hline \multirow[t]{4}{*}{$\begin{array}{l}\text { Army Research } \\
\text { Office (ARO) }\end{array}$} & $\begin{array}{l}\text { General Dynamics Robotics Systems } \\
\text { (lead); Carnegie Mellon University; } \\
\text { Florida A\&M University; University of } \\
\text { Central Florida; University of } \\
\text { Pennsylvania; Boston Dynamics, } \\
\text { QinetiQ North America; CalTech/Jet } \\
\text { Propulsion Laboratory }\end{array}$ & $\begin{array}{l}\text { The Robotics Collaborative } \\
\text { Technology Alliance; Robotics } \\
\text { Collaborative Technology Alliance }\end{array}$ & $\begin{array}{l}\text { Cooperative } \\
\text { Agreement }\end{array}$ & $\begin{array}{l}\text { Creation of autonomous robots } \\
\text { that can effectively team with } \\
\text { soldiers }\end{array}$ & 5 years \\
\hline & $\begin{array}{l}\text { Arizona State University (lead); } \\
\text { Arizona State List of Partners }\end{array}$ & $\begin{array}{l}\text { The Flexible Display Center (FDC); } \\
\text { Flexible Display Website }\end{array}$ & $\begin{array}{l}\text { Cooperative } \\
\text { Agreement }\end{array}$ & $\begin{array}{l}\text { Advance flexible display } \\
\text { technologies }\end{array}$ & 10 years \\
\hline & $\begin{array}{l}\text { Stanford University (lead); High } \\
\text { Performance Technologies, Inc.; } \\
\text { Morgan State University; New Mexico } \\
\text { State University at Las Cruces; } \\
\text { University of Texas at El Paso; NASA } \\
\text { Ames Research Center }\end{array}$ & $\begin{array}{l}\text { Army High Performance Computing } \\
\text { Research Center (AHPCRC); } \\
\text { Stanford AHPCRC Website }\end{array}$ & $\begin{array}{l}\text { Cooperative } \\
\text { Agreement }\end{array}$ & High-performance computing & 7 years \\
\hline & $\begin{array}{l}\text { Defense Advanced Research Projects } \\
\text { Agency (DARPA); Massachusetts } \\
\text { Institute of Technology (MIT); National } \\
\text { Institutes of Health (NIH); Draper } \\
\text { Laboratory, MatTek Corporation; } \\
\text { Zyoxel Ltd. }\end{array}$ & $\begin{array}{l}\text { Barrier-Immune-Organ: } \\
\text { MIcrophysiology, Microenvironment } \\
\text { Engineered Tissue Construct } \\
\text { Systems (BIO-MIMETICS); News } \\
\text { Article MIT Biomimetic Robotics } \\
\text { Laboratory }\end{array}$ & $\begin{array}{l}\text { Cooperative } \\
\text { Agreement }\end{array}$ & Tissue engineering & 5 years \\
\hline
\end{tabular}




\begin{tabular}{|c|c|c|c|c|c|}
\hline $\begin{array}{c}\text { DOD } \\
\text { Laboratory }\end{array}$ & University Partner(s) & Name of Initiative & Mechanism & Research Area & Duration \\
\hline & $\begin{array}{l}\text { University of Nebraska at Lincoln; } \\
\text { DEKA Research and Development } \\
\text { Corporation; Walter Reed Medical } \\
\text { Center; Johns Hopkins; Department of } \\
\text { Veterans Affairs }\end{array}$ & $\begin{array}{l}\text { Revolutionizing Prosthetics; } \\
\text { DARPA Revolutionizing Prosthetics } \\
\underline{\text { Website }}\end{array}$ & $\begin{array}{l}\text { Cooperative } \\
\text { Agreement }\end{array}$ & $\begin{array}{l}\text { Making a new prosthetic arm } \\
\text { using Segway technology }\end{array}$ & 8 years \\
\hline & University of Southern California & $\begin{array}{l}\text { Institute for Creative Technologies; } \\
\text { Institute for Creative Technologies } \\
\underline{\text { Website }}\end{array}$ & $\begin{array}{l}\text { Cooperative } \\
\text { Agreement, } \\
\text { University } \\
\text { Affiliated } \\
\text { Research } \\
\text { Center (UARC) }\end{array}$ & $\begin{array}{l}\text { Virtual reality training for } \\
\text { traumatic brain injury and } \\
\text { psychological impact }\end{array}$ & 15 years \\
\hline & $\begin{array}{l}\text { University of California, Santa Barbara; } \\
\text { California Institute of Technology } \\
\text { (Caltech); MIT }\end{array}$ & $\begin{array}{l}\text { Institute of Collaborative } \\
\text { Biotechnologies; Institute of } \\
\text { Collaborative Biotechnologies } \\
\underline{\text { Website }}\end{array}$ & $\begin{array}{l}\text { Cooperative } \\
\text { Agreement, } \\
\text { UARC }\end{array}$ & $\begin{array}{l}\text { Biologically inspired research, } \\
\text { such as on-signal processing }\end{array}$ & 10 years \\
\hline & MIT & $\begin{array}{l}\text { Institute of Soldier } \\
\text { Nanotechnologies; Institute of } \\
\text { Soldier Nanotechnologies Website }\end{array}$ & $\begin{array}{l}\text { Cooperative } \\
\text { Agreement, } \\
\text { UARC }\end{array}$ & $\begin{array}{l}\text { Nanotechnology - materials, } \\
\text { soldier medicine, protective } \\
\text { systems, hazardous } \\
\text { substances, and systems } \\
\text { integration for operations }\end{array}$ & 11 years \\
\hline & $\begin{array}{l}\text { BAE (Industrial Lead); Jet Propulsion } \\
\text { Laboratory (Integration Principal } \\
\text { Member); University of Maryland } \\
\text { (Microsystem Mechanics Principal } \\
\text { Member); University of Michigan } \\
\text { (Microelectronics Principal Member); } \\
\text { University of Pennsylvania (Processing } \\
\text { for Autonomous Operation Principal } \\
\text { Member); University of California, } \\
\text { Berkeley; Caltech, Georgia Tech; } \\
\text { Harvard University; MIT; North } \\
\text { Carolina Agricultural and Technical } \\
\text { (A\&T) State University; University of } \\
\text { New Mexico }\end{array}$ & $\begin{array}{l}\text { Micro Autonomous Systems and } \\
\text { Technology (MAST); Army MAST } \\
\text { Website } \\
\end{array}$ & $\begin{array}{l}\text { Cooperative } \\
\text { Technical } \\
\text { Agreement } \\
\text { (CTA) }\end{array}$ & $\begin{array}{l}\text { Improving warfighter situational } \\
\text { awareness }\end{array}$ & $\begin{array}{l}5 \text { to } 10 \\
\text { years } \\
\text { (possible } \\
\text { renewal } \\
\text { after } \\
5 \text { years) }\end{array}$ \\
\hline
\end{tabular}




\begin{tabular}{|c|c|c|c|c|c|}
\hline $\begin{array}{c}\text { DOD } \\
\text { Laboratory }\end{array}$ & University Partner(s) & Name of Initiative & Mechanism & Research Area & Duration \\
\hline & $\begin{array}{l}\text { DCS Corp (Industrial Lead, Integration } \\
\text { Principal Member); Taiwan Brain } \\
\text { Research Center; University of } \\
\text { California, San Diego; University of } \\
\text { Michigan; University of Texas at San } \\
\text { Antonio; University of Osnabruck }\end{array}$ & $\begin{array}{l}\text { Cognition and Neuroergonomics; } \\
\text { Cognition and Neuroergonomics } \\
\underline{\text { Website }}\end{array}$ & $\begin{array}{l}\text { Cooperative } \\
\text { Research } \\
\text { Agreement } \\
\text { (CRA) }\end{array}$ & $\begin{array}{l}\text { Humans learn and perceive } \\
\text { information and interact with } \\
\text { man-machine interfaces- } \\
\text { neurocognitive performance, } \\
\text { advanced computational } \\
\text { approaches, and } \\
\text { neurotechnologies }\end{array}$ & 4 years \\
\hline & $\begin{array}{l}\text { BBN Technologies, Interdisciplinary } \\
\text { Research Center (IRC); Pennsylvania } \\
\text { State University, Communications } \\
\text { Networks Academic Research Center } \\
\text { (CNARC); University of Illinois-Urbana } \\
\text { Champaign, Information Networks } \\
\text { Academic Research Center (INARC); } \\
\text { Rensselaer Polytechnic Institute, } \\
\text { Social/Cognitive Networks Academic } \\
\text { Research Center (SNARC) }\end{array}$ & $\begin{array}{l}\text { Network Sciences; Network } \\
\text { Sciences Website }\end{array}$ & CRA & Network sciences & 4 years \\
\hline & $\begin{array}{l}\text { Johns Hopkins University (Lead } \\
\text { Research Organization); Caltech; } \\
\text { Rutgers University; University of } \\
\text { Delaware }\end{array}$ & $\begin{array}{l}\text { Materials in Extreme Dynamic } \\
\text { Environments (MEDE); MEDE } \\
\text { Website }\end{array}$ & CTA & $\begin{array}{l}\text { Modeling and simulation, } \\
\text { bridging the scales, advanced } \\
\text { experimental techniques and } \\
\text { computational validation, multi- } \\
\text { scale material metrics, and } \\
\text { processing and synthesis }\end{array}$ & 2 years \\
\hline & $\begin{array}{l}\text { University of Utah (Lead Research } \\
\text { Organization); Boston University; } \\
\text { Rensselaer Polytechnic Institute }\end{array}$ & $\begin{array}{l}\text { Multi-Scale Multidisciplinary } \\
\text { Modeling of Electronic Materials } \\
\text { (MSME); MSME Program Website }\end{array}$ & CTA & $\begin{array}{l}\text { Electrochemical energy } \\
\text { devices, hybrid photonic } \\
\text { devices, and heterogeneous } \\
\text { metamorphic electronics }\end{array}$ & 2 years \\
\hline $\begin{array}{l}\text { ARO Edgewood } \\
\text { Chemical and } \\
\text { Biological Center } \\
\text { (ECBC) }\end{array}$ & $\begin{array}{l}\text { Virginia Technology Polytechnic } \\
\text { Institute and State University }\end{array}$ & $\begin{array}{l}\text { The Morris Group; Research } \\
\text { Program Website }\end{array}$ & $\begin{array}{l}\text { Funding by the } \\
\text { Chemical } \\
\text { Sciences } \\
\text { Division of } \\
\text { ECBC }\end{array}$ & $\begin{array}{l}\text { Surface chemistry, chemical } \\
\text { events that occur at the surface } \\
\text { interface between two phases }\end{array}$ & $\begin{array}{l}\text { At least } \\
\text { since } 2008\end{array}$ \\
\hline
\end{tabular}




\begin{tabular}{|c|c|c|c|c|c|}
\hline $\begin{array}{c}\text { DOD } \\
\text { Laboratory }\end{array}$ & University Partner(s) & Name of Initiative & Mechanism & Research Area & Duration \\
\hline $\begin{array}{l}\text { Naval Surface } \\
\text { Warfare Center } \\
\text { (NSWC), Crane } \\
\text { Division }\end{array}$ & Purdue University & $\begin{array}{l}\text { Purdue Institute for Defense } \\
\text { Innovation; News Article }\end{array}$ & $\begin{array}{l}\text { Cooperative } \\
\text { Research and } \\
\text { Development } \\
\text { Agreement } \\
\text { (CRADA) }\end{array}$ & $\begin{array}{l}\text { Energy storage and power } \\
\text { management, and electronic } \\
\text { warfare }\end{array}$ & 4 years \\
\hline Army & $\begin{array}{l}\text { Michigan Technological University } \\
\text { Keweenaw Research Center (MUKRC) }\end{array}$ & $\begin{array}{l}\text { Tank Automotive Research, } \\
\text { Development and Engineering } \\
\text { Center (TARDEC) Program; } \\
\text { MUKRC Program History } \\
\end{array}$ & $\begin{array}{l}\text { Research } \\
\text { funding }\end{array}$ & $\begin{array}{l}\text { Research program focusing on } \\
\text { education, vehicle testing } \\
\text { facilities }\end{array}$ & 20 years \\
\hline \multirow[t]{5}{*}{$\begin{array}{l}\text { Air Force } \\
\text { Research } \\
\text { Laboratory } \\
\text { (AFRL) }\end{array}$} & $\begin{array}{l}\text { Johns Hopkins University (Lead); } \\
\text { Caltech; Rutgers, University of } \\
\text { Delaware }\end{array}$ & $\begin{array}{l}\text { High-Rate Deformation; Caltech } \\
\text { News Article }\end{array}$ & $\begin{array}{l}\text { Centers of } \\
\text { Excellence }\end{array}$ & $\begin{array}{l}\text { Heterogeneous materials at } \\
\text { high strain and pressures, } \\
\text { develop engineered } \\
\text { microstructures and functional } \\
\text { nanomaterial for mitigating } \\
\text { shock damage }\end{array}$ & - \\
\hline & $\begin{array}{l}\text { Johns Hopkins University; Ohio State } \\
\text { University }\end{array}$ & $\begin{array}{l}\text { Scientific Challenges Associated } \\
\text { with Multi-Materials Systems with } \\
\text { Adaptive Microstructures for } \\
\text { Aerospace Applications; Center of } \\
\text { Excellence Description }\end{array}$ & $\begin{array}{l}\text { Centers of } \\
\text { Excellence }\end{array}$ & $\begin{array}{l}\text { Modeling of mechanical } \\
\text { behavior of heterogeneous } \\
\text { materials }\end{array}$ & - \\
\hline & $\begin{array}{l}\text { University of Michigan (lead } \\
\text { institution); University of California, Los } \\
\text { Angeles (UCLA); Michigan } \\
\text { Technological University; Penn State } \\
\text { University; Colorado State University; } \\
\text { MSNW LLC/University of Washington }\end{array}$ & $\begin{array}{l}\text { Michigan/Air Force Center of } \\
\text { Excellence in Electric Propulsion } \\
\text { (MACEEP); MACEEP Website }\end{array}$ & $\begin{array}{l}\text { Centers of } \\
\text { Excellence }\end{array}$ & $\begin{array}{l}\text { High-plasma propulsion, } \\
\text { electrospray propulsion, time- } \\
\text { resolved plasma diagnostics, } \\
\text { modeling and simulation }\end{array}$ & 5 years \\
\hline & George Mason University & $\begin{array}{l}\text { Center of Excellence in } \\
\text { Neuroergonomics, Technology, } \\
\text { and Cognition (CENTEC); } \\
\text { CENTEC Website }\end{array}$ & $\begin{array}{l}\text { Centers of } \\
\text { Excellence }\end{array}$ & $\begin{array}{l}\text { Human brain function for } \\
\text { mental and physical } \\
\text { performance, design } \\
\text { technologies, systems, and } \\
\text { environments for optimal work }\end{array}$ & 5 years \\
\hline & Georgia Tech Research Corporation & $\begin{array}{l}\text { Air Force Center of Excellence on } \\
\text { Bio-nano-enabled } \\
\text { Inorganic/Organic Nanostructures } \\
\text { and Improved Cognition (BIONIC); } \\
\text { BIONIC Website }\end{array}$ & $\begin{array}{l}\text { Centers of } \\
\text { Excellence }\end{array}$ & $\begin{array}{l}\text { Functional nanocomposites, } \\
\text { adaptive nanocomposites, } \\
\text { cognitive enhancements }\end{array}$ & 5 years \\
\hline
\end{tabular}




\begin{tabular}{|c|c|c|c|c|c|}
\hline $\begin{array}{c}\text { DOD } \\
\text { Laboratory }\end{array}$ & University Partner(s) & Name of Initiative & Mechanism & Research Area & Duration \\
\hline & John Hopkins University & $\begin{array}{l}\text { Centers of Excellence on } \\
\text { Integrated Materials Modeling } \\
\text { (CEIMM); CEIMM Website }\end{array}$ & $\begin{array}{l}\text { Centers of } \\
\text { Excellence }\end{array}$ & $\begin{array}{l}\text { Physics-based multi-scale } \\
\text { models, multi-scale } \\
\text { characterization and virtual } \\
\text { models, probabilistic modeling } \\
\text { and uncertainty quantification, } \\
\text { and multi-scale experimental } \\
\text { methods }\end{array}$ & - \\
\hline $\begin{array}{l}\text { Defense } \\
\text { Advanced } \\
\text { Research Projects } \\
\text { Agency (DARPA) }\end{array}$ & $\begin{array}{l}\text { University of Texas at Austin, Cockrell } \\
\text { School of Engineering }\end{array}$ & $\begin{array}{l}\text { Center for Energy Security; } \\
\text { Research Centers Website }\end{array}$ & $\begin{array}{l}\text { Centers of } \\
\text { Excellence }\end{array}$ & $\begin{array}{l}\text { Technology transfer related to } \\
\text { energy }\end{array}$ & - \\
\hline
\end{tabular}





\section{Appendix C. \\ Interview Protocol}

\section{Introduction}

The Department of Defense (DOD) funds a significant amount of research at the universities through a number of grant programs. In addition, universities have partnerships for conducting research collaboratively with the DOD laboratories through mechanisms such as Cooperative Research and Development Agreements (CRADAs), facility and personnel sharing mechanisms, and up to informal 1:1 interactions between researchers. We are interested in this $\left(2^{\text {nd }}\right)$ type of DOD laboratory-university interaction.

\section{Questions}

1. Please tell us about yourself.

a. Your current position: Vice President for Research

b. Have you had experience with the DOD laboratories in previous positions? In this position?

\section{Nature and Extent of Interaction}

1. Can you tell us about partnerships between your university and the DOD laboratories?

a. How were the partnerships initiated? By the laboratory, university, other? By research faculty, the technology transfer office, other?

b. What partnership mechanism was used?

c. Was this an ongoing partnership or a one-off project?

d. What made these partnerships successful?

e. Were there any notable outcomes you would like to share?

\section{Motivations/Incentives to Partner}

1. What is the motivation for your university to partner with the DOD laboratories?

a. Possibilities include access to laboratory facilities, funding, the opportunity to work on....

2. Do any successful incentive programs come to mind?

3. Do you have any suggestions for incentives or ways to motivate either laboratories or universities to engage in more partnerships? 


\section{Benefits from Partnering}

1. In your opinion, what are the benefits (either already experienced or potential) of partnering with a DOD laboratory for a university?

2. In your opinion, what are the benefits of partnering with a university for a DOD laboratory?

3. Do you have ideas for how to measure these benefits?

\section{Awareness}

1. Are researchers at your university aware of opportunities in working with the DOD laboratories?

a. Are there are ways that DOD can create more awareness of these opportunities on your campus?

2. What characteristics do you think are important for a university/researcher to engage in a partnership with a DOD laboratory?

a. For example, funding amounts, geographic proximity to a DOD laboratory, science and technology (S\&T) alignment with the DOD mission.

\section{Barriers to Partnering and Strategies for Overcoming Barriers}

1. Are you aware of any barriers to partnering with the DOD laboratories?

a. For example, publication restrictions, International Traffic in Arms Regulations (ITAR), prohibition of non-citizens.

2. Do these barriers stem from the university or laboratory or both?

3. Are you aware of any strategies for overcoming these barriers?

\section{Access}

1. Is there any DOD laboratory you would like to partner with, but haven't yet? Why not?

2. Are you interested in engaging in more partnerships?

\section{Policy Suggestions to Facilitate Interactions}

1. Do you have any policy suggestions for streamlining partnership interactions between the DOD laboratories and the universities?

\section{Miscellaneous}

1. When engaging with universities, whom do you recommend we speak with? We have been speaking with Vice Presidents of Research. Do you recommend we speak to researchers or with the technology transfer office?

2. Could you recommend others who are knowledgeable about DOD laboratoryuniversity partnerships and whom we could talk to?

3. Any final thoughts? 


\section{Appendix D. \\ A Guidebook for Universities Partnering with the Department of Defense National Laboratories}

\section{Table of Contents}

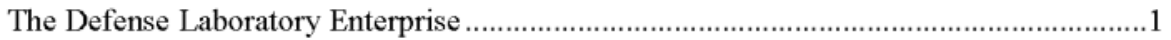

Partnering with the DOD Laboratories .......................................................................

A. Research Partnership Agreements ...................................................................

1. Cooperative Research and Development Agreements (CRADAs)...............5

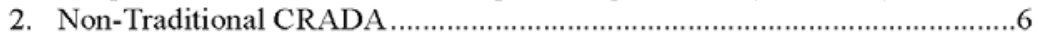

3. Cooperative Agreement (CA) ………………………………………......6

4. Collaborative Technology Alliances (CTA) and Collaborative Research Alliances (CRA)

B. Resource Use Agreements (RUA) …………………………………….....

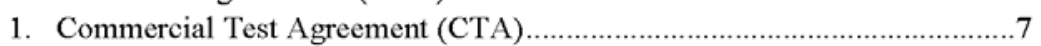

2. Test Service Agreement (TSA) _..................................................................

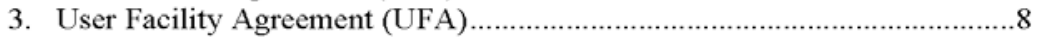

C. Personnel Exchange Agreements ...................................................................... 8

1. Intergovernmental Personnel Act (IPA) Assignments ..................................8

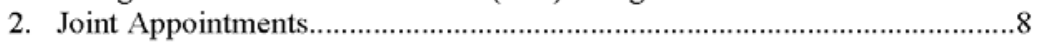

D. Educational Agreements...........................................................................

1. Educational Partnership Agreement (EPA) ……………………………....9

2. Other Fellowship, Internship, and Sabbatical Leave Programs ....................9

E. Other Partnership Agreements ..................................................................... 10

1. University Affiliated Research Centers (UARC) ......................................10

2. Other Transaction Authority (OTA) ......................................................

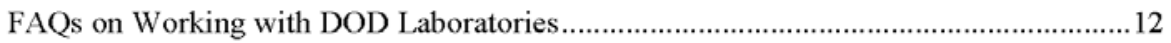

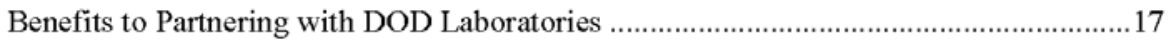

1. Access to unique capabilities …………................................................17

2. Guidance for existing research ......................................................17

3. Opportunities for new research ...............................................................17

4. Leveraged outcomes and funding ............................................................18

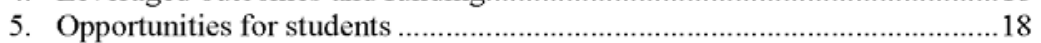

Notable Partnership Examples.................................................................................... 19

1. Education partnerships with NSWC Crane ……………...........................19

2. ECBC surface chemistry collaboration ...................................................

3. AFRL University Partnerships .............................................................20

4. Electric Ship Research and Development Consortium (ESRDC) ................20

List of DOD Laboratories and Points of Contact..........................................................22 


\section{The Defense Laboratory Enterprise}

This document serves a handbook for understanding the Department of Defense (DOD) Laboratory Enterprise and for identifying the possible mechanisms by which nonFederal parties, particularly universities, can engage in research collaboration with the Defense laboratories.

The mission of the Defense Laboratory Enterprise (DLE) is to advance the capabilities of the warfighter and meet the science, technology, and research needs for the country's defense. The laboratories of the DLE are operated by the armed services, each of which are responsible for particular laboratories, centers and agencies (herein referred to as laboratories) in the system. They are also overseen by the DLE directorate in the Office of the Secretary of Defense for Research and Engineering (ASDR\&E) within the Office of the Secretary of Defense (OSD).

In total, the DLE entails a budget of approximately $\$ 30$ billion a year, about $40 \%$ of which is spent directly on research performed within the laboratories. With those funds, the DLE is able to address a diverse set of science and technology challenges, and many laboratories have established themselves as world leaders in research areas like lasers and armor technologies. In its entirety, the DLE laboratory network encompasses over 39,000 scientists, engineers, and researchers working actively in a wide range of research fields at 67 locations in 22 different states across the country. A detail list of the various laboratories that comprise the DLE can be found starting on page 19 of this guidebook. In addition, the detailed description of the missions, core competencies, facilities, locations, and activities of the DLE can be accessed here. ${ }^{1}$

While much of the laboratory budget is used to perform in-house research, more than $60 \%$ is available for "out-of-house" work through a $\operatorname{mix}$ of collaborative partnerships and extramural grants. Defenses laboratories are interested in engaging with non-Federal research for many reasons, a few of which include obtaining access to cutting-edge scientific research, connecting with top level scientists and engineers in academia and the private sector, and enabling non-Federal U.S. universities and research institutes to leverage the unique capabilities and facilities that the laboratories have to offer. Accordingly, there are many opportunities for cooperative research partnerships between DOD laboratories and universities. The remainder of this handbook describes the different mechanisms by which non-Federal parties can collaborate with the Defense

1 https:/acc.dau.mil/adl/en-US/461198/file/59229/Defense_Laboratory_Enterprise.pdf. 
Laboratories, provides answers to some Frequently Asked Questions on collaboration, and highlights the benefits of partnering and notable partnerships currently in place. 


\section{Partnering with the DOD Laboratories}

This guidebook is intended to focus primarily on partnership mechanisms by which universities and DOD Laboratories can engage in joint-effort collaborative research. Partnerships between universities and DOD laboratories can take many different forms. While the DOD does provide grant-based programs for academic institutions, collaborative partnerships between universities and DOD laboratories are typically considered to entail the bidirectional exchange of workforce, materials, intellectual property, or more basic ideas between the two entities.

This guidebook describes the different partnership mechanisms available. These agreements can be categorized thematically:

1. Research partnership agreements provide for joint and collaborative research

2. Resource-use agreements allow non-Federal partners to utilize Federal laboratory equipment for testing and evaluation

3. Personnel exchange agreements enable the exchange of researchers (usually those more advanced in their careers) to be temporarily or indefinitely employed by both the originating and destination organizations

4. Educational agreements offer opportunities to undergraduate and graduate students, post-doctoral fellows, and professors to extend their education and research experience and for universities to co-develop educational initiatives with Federal laboratories

Other mechanisms available for partnering are also described, but are generally less used then those listed above. The following table summarizes the agreement mechanisms available and some of their characteristics, which are further elaborated in detail below. 


\begin{tabular}{|c|c|c|c|c|c|c|c|}
\hline $\begin{array}{l}\text { Type of } \\
\text { Agreement }\end{array}$ & $\begin{array}{l}\text { Agreement or } \\
\text { Mechanism }\end{array}$ & Primary purpose & $\begin{array}{l}\text { Approx. } \\
\text { Length }\end{array}$ & $\begin{array}{l}\text { Collab. in } \\
\text { Research }\end{array}$ & $\begin{array}{l}\text { Personnel } \\
\text { Exchange }\end{array}$ & $\begin{array}{l}\text { Lab. } \\
\text { Facilities } \\
\text { Access }\end{array}$ & $\begin{array}{l}\$ \$ \\
\text { from } \\
\text { Gov. }\end{array}$ \\
\hline \multirow[t]{4}{*}{$\begin{array}{l}\text { Research } \\
\text { Partnership } \\
\text { Agreements }\end{array}$} & CRADA & $\begin{array}{l}\text { Contract for collaborative research; often } \\
\text { used when there is the expectation of } \\
\text { producing a commercial technology }\end{array}$ & $\begin{array}{l}\text { Medium } \\
\text { to long } \\
\text { term }\end{array}$ & Yes & Yes & Yes & No \\
\hline & $\begin{array}{l}\text { Non- } \\
\text { Traditional } \\
\text { CRADA }\end{array}$ & $\begin{array}{l}\text { CRADA tailored for specialized purposes } \\
\text { e.g. clinical trial partnerships, materials } \\
\text { transfer }\end{array}$ & \begin{tabular}{|l} 
Medium \\
to long \\
term
\end{tabular} & Yes & Yes & Yes & No \\
\hline & $\begin{array}{l}\text { Cooperative } \\
\text { Agreement }\end{array}$ & $\begin{array}{l}\text { Used for collaborative research projects } \\
\text { that are exploratory in nature. Must be } \\
\text { competed. }\end{array}$ & $\begin{array}{l}\text { Medium } \\
\text { to long } \\
\text { term }\end{array}$ & Yes & Yes & Yes & Yes \\
\hline & $\begin{array}{l}\text { Collaborative } \\
\text { Research/ } \\
\text { Technology } \\
\text { Alliance }\end{array}$ & $\begin{array}{l}\text { A special form of a CA that emphasizes } \\
\text { multi-disciplinary collaboration and often } \\
\text { combines gov., industry, and university } \\
\text { partners. Must be competed. }\end{array}$ & $\begin{array}{l}\text { Medium } \\
\text { to long } \\
\text { term }\end{array}$ & Yes & Yes & Yes & Yes \\
\hline \multirow[t]{3}{*}{$\begin{array}{l}\text { Resource } \\
\text { Use } \\
\text { Agreements }\end{array}$} & $\begin{array}{l}\text { Commercial } \\
\text { Test } \\
\text { Agreement }\end{array}$ & $\begin{array}{l}\text { Allows partners to test materials, } \\
\text { equipment, models, or software using gov. } \\
\text { laboratory equipment }\end{array}$ & $\begin{array}{l}\text { Short } \\
\text { term }\end{array}$ & No & No & Yes & No \\
\hline & $\begin{array}{l}\text { Test Service } \\
\text { Agreements }\end{array}$ & $\begin{array}{l}\text { Allows partners to purchase testing } \\
\text { services for materials, equipment, models, } \\
\text { or software from government laboratories }\end{array}$ & $\begin{array}{l}\text { Short } \\
\text { term }\end{array}$ & No & No & Yes & No \\
\hline & $\begin{array}{l}\text { User Facilities } \\
\text { Agreement }\end{array}$ & $\begin{array}{l}\text { Enables partners to conduct research } \\
\text { experiments on unique government } \\
\text { laboratory equipment and facilities }\end{array}$ & $\begin{array}{l}\text { Short } \\
\text { term }\end{array}$ & No & No & Yes & No \\
\hline \multirow[t]{2}{*}{$\begin{array}{l}\text { Personnel } \\
\text { Exchange } \\
\text { Agreements }\end{array}$} & $\begin{array}{l}\text { Inter- } \\
\text { governmental } \\
\text { Personnel Act }\end{array}$ & $\begin{array}{l}\text { Used for exchanges of Federal laboratory } \\
\text { and university personnel }\end{array}$ & $\begin{array}{l}\text { Short } \\
\text { term }\end{array}$ & No & Yes & No & No \\
\hline & $\begin{array}{l}\text { Joint } \\
\text { Appointments }\end{array}$ & $\begin{array}{l}\text { Allows university or Federal laboratory } \\
\text { personnel to be employed at multiple } \\
\text { institutions }\end{array}$ & $\begin{array}{l}\text { Medium } \\
\text { to long } \\
\text { term }\end{array}$ & No & Yes & No & No \\
\hline \multirow[t]{2}{*}{$\begin{array}{l}\text { Educational } \\
\text { Agreements }\end{array}$} & $\begin{array}{l}\text { Educational } \\
\text { Partnership } \\
\text { Agreements }\end{array}$ & $\begin{array}{l}\text { Used to allow government laboratories and } \\
\text { universities to work together to develop } \\
\text { educational programs that further both } \\
\text { partners' missions }\end{array}$ & $\begin{array}{l}\text { Medium } \\
\text { term }\end{array}$ & Varies & Varies & Varies & Varies \\
\hline & $\begin{array}{l}\text { Fellowship, } \\
\text { Internship, } \\
\text { and } \\
\text { Sabbatical } \\
\text { Leave } \\
\text { Programs } \\
\end{array}$ & $\begin{array}{l}\text { A variety of mechanisms available for both } \\
\text { student and research professors, including } \\
\text { summer internships and fellowships and } \\
\text { faculty leave programs. Vary by service }\end{array}$ & $\begin{array}{l}\text { Short } \\
\text { term }\end{array}$ & Varies & Yes & Varies & Varies \\
\hline \multirow[t]{3}{*}{$\begin{array}{l}\text { Other } \\
\text { Partnership } \\
\text { Agreements }\end{array}$} & $\begin{array}{l}\text { University } \\
\text { Affiliated } \\
\text { Research } \\
\text { Center }\end{array}$ & $\begin{array}{l}\text { Long-term partnerships that creates a } \\
\text { university led research center to meet } \\
\text { DOD needs. Must be competed; cannot be } \\
\text { solicited. }\end{array}$ & $\begin{array}{l}\text { Long } \\
\text { term }\end{array}$ & Yes & Yes & No & Yes \\
\hline & $\begin{array}{l}\text { Centers of } \\
\text { Excellence }\end{array}$ & $\begin{array}{l}\text { An Air Force mechanism that is similar to } \\
\text { that of the UARC. Must be competed; } \\
\text { cannot be solicited. }\end{array}$ & $\begin{array}{l}\text { Long } \\
\text { term }\end{array}$ & Yes & Yes & No & Yes \\
\hline & $\begin{array}{l}\text { Other } \\
\text { Transaction } \\
\text { Authority }\end{array}$ & $\begin{array}{l}\text { Used for a partnership that does not fit the } \\
\text { above agreement mechanisms. Special } \\
\text { conditions apply. }\end{array}$ & Varies & Varies & Varies & Varies & Varies \\
\hline
\end{tabular}




\section{A. Research Partnership Agreements}

Research partnership agreements typically entail active cooperative research, with researchers from both the DOD laboratories and the university partner working together to answer specific research questions or pursue specific technological outcomes. The type of agreement that is appropriate for the partnership often depends on the type of research being performed and the expectation of any commercial technology outcomes. Agreement mechanisms in this category include CRADAs, CAs, and CRAs/CTAs.

In addition to the formal mechanisms described below, there are many opportunities for informal collaboration between DOD laboratory researchers and university scientists. DOD laboratory researchers are often aware of the progress of military grant-funded research at the universities, particularly for big initiatives such as those falling under the Multiple Discipline University Research Initiative (MURI). This enables them to reach out to professors when they see a potential for exchanging ideas and spinning off a project into future work for the laboratory with the university. Furthermore, laboratory and university researchers can meet and interact at conferences, follow each other's research, and co-author publications. This type of investigator-to-investigator collaboration by and large does not require a formalized agreement.

\section{Cooperative Research and Development Agreements (CRADAs)}

CRADAs are formal contractual agreements between Federal laboratories and nonFederal entities to perform collaborative research under a legal framework that will protect the interest of both parties. These agreements are intended to create a safe and well-protected partnership environment by ensuring the preservation of background intellectual property (IP); pre-negotiating the ownership of any resulting IP; and any delineating rules, regulations, or expectations that can impact either party, CRADAs with the Federal laboratories can be established by contacting the laboratory's Office of Research and Technology Application (ORTA) or other partnership offices within the laboratory. Generally, the DOD laboratories have a standardized template for CRADA contracts, which outlines the Federal laboratory's traditional funding, publications, export control and IP obligations. If universities are interested in about additional opportunities beyond what a standard CRADA provides, they can refer to the following section for a few options or inquire about negotiating these terms with the Federal laboratory's ORTA.

It is important to note that the Federal laboratory cannot, by law, provide funds to universities under CRADAs. This allows for these agreements to fall outside scope of Federal Acquisition Regulations (FAR) or Defense Acquisition Regulations. Thus, depending on the terms of the contract, Federal and non-Federal institutions are able to share facilities, personnel, services, equipment and other resources, but only the nonFederal partner can provide funds to support the project. 
CRADAs provide for protection of intellectual property, and Federal laboratories are required to provide their partners with the option of an exclusive license for a prenegotiated field of use, but can also offer non-exclusive or limited patents. By law, these patents are granted to partners only under the condition that Federal laboratory partners retain nonexclusive licenses to practice invention and the Government maintains "marchin" rights to re-license invention if the partner has not sufficiently taken steps to apply or commercialize the invention.

\section{Non-Traditional CRADA}

Non-traditional CRADAs come in various forms but are used for specialized purposes such as clinical trial partnerships, materials transfer, or other technical assistance. Nontraditional CRADAs are particularly useful for transferring materials between partners outside of the Federal Acquisition Regulations, since DOD laboratories are not authorized to enter into Material Transfer Agreements (MTAs). These special-purpose CRADAs can be simplified from traditional CRADAs and offer the benefit of being quicker and easier to execute. Many of the regulations of traditional CRADAs such as the Federal funding restriction and IP protection applies to non-traditional CRADAs as well.

\section{Cooperative Agreement (CA)}

Cooperative Agreements are contracts in which both partners have enforceable duties to carry out a specific research project. CAs are in many ways similar to CRADAs with the exception that unlike CRADAs, Federal funding can be exchanged through a CA mechanism, along with other physical resources, i.e., equipment and personnel. CAs are generally intended for the exchange of ideas that may still be in the exploratory or "preconceptual" stage with a contractual protection of intellectual property rights. CAs can also be negotiated and drafted through a specific Federal laboratory's ORTA.

\section{Collaborative Technology Alliances (CTA) and Collaborative Research Alliances (CRA)}

CTAs and CRAs are a form of cooperative agreement developed under the DOD's Other Transaction Authority (see OTA below). These agreements have been used by the DOD laboratories, particularly the Army Research Laboratory, to organize and manage a consortium of industry and academic partners. The CRA or CTA is proposed by a service laboratory that is seeking to conduct research and development focused on complex, multidisciplinary and rapidly transitioning technologies for the support of the U.S. Armed Forces. Universities are essential in these alliances as they are at the cutting edge of innovative research, while industry partners use their expertise to leverage the technology's transition to the market. The Army and other government agencies guide the work of these alliances to ensure the most productive use of their resources. CTAs through the Army 
Research Laboratory have last from 5-8 years and can be resourced at levels of \$3 million to $\$ 8$ million annually. Contact information and more details on Army Research Laboratory's CTAs can be found on their "Collaborative Alliances" web page.

\section{B. Resource Use Agreements (RUA)}

When universities or research faculty are solely interested in using specific DOD facilities, equipment, personnel or expertise to test materials, equipment, models, computer software, and other items, they can choose to enter into resource use agreements with the DOD. For a negotiated fee that is used to reimburse the use of the equipment, DOD laboratories can make their facilities and capabilities available to universities These fees are determined at the discretion of individual laboratories, so university researchers interested in using DOD laboratory equipment and resources should contact the Technology Transfer Office of the specific laboratory of interest to find out more about the applicable fees.

Unlike the contractual agreements described above, Resource Use Agreements should only be used when the Federal laboratory has no technical collaborations with the university. Types of resource use agreements include Commercial Test, Test Service, and User Facility Agreements. While all three types of RUAs allow for use of DOD resources for testing and evaluation, there are distinctions between the three that are briefly explained below. More detail on the RUAs available for specific Federal laboratories can be found at their Technology Transfer Offices or, sometimes, their Business Interface Offices.

\section{Commercial Test Agreement (CTA)}

Commercial Test Agreements allow partners to use the services of a Federal laboratory, center, or test facility to test materials, equipment, models, computer software, CTAs are used by the Air Force (FLC 2008) and the U.S. Army Medical Research and Materiel Command (AMRMC) (U.S. Army Medical Research Acquisition Activity 2009).

\section{Test Service Agreement (TSA)}

The Department of Defense is authorized to sell services for the testing of materials, equipment, models, computer software, and other items under Test Service Agreements (TSAs) are not intended to be used for research studies nor can they constitute undue competition with the private sector. Partners may be individuals, partnerships, corporations, associations, state, local or tribunal governments, or an agency or instrumentality of the United States, but not agencies of foreign governments (10 U.S.C $\$ 2539$ b). 


\section{User Facility Agreement (UFA)}

User Facility Agreements (UFAs), or Facility Use Agreements for the National Institute of Standards and Technology (NIST) (Lynch 2005), allow outside parties access to the unique research equipment and facilities of Federal laboratories. Typically, UFAs allow for fabrication, calibration, testing, and evaluation of products and processes. UFAs are performed and funded by the partner, who retains all patent rights to inventions subject to the government's royalty-free license. Many laboratories retain master UFAs with a number of partners to facilitate access for their employees. The Department of Energy, NIST and Army use UFAs (FLC 2008)Personnel Exchange Agreements.

\section{Personnel Exchange Agreements}

The DOD offers several avenues for personnel exchange between university faculty DOD laboratories research staff. Two primary mechanisms include joint appointments and interpersonal exchange through the Intergovernmental Personnel Act. Certain restrictions may apply to these exchanges as DOD laboratories may require incoming non-Federal personnel to obtain a security clearance prior to their working at DOD facilities and disclose of any potential conflict-of-interests. Information on such requirements is usually available at the Technology Transfer Offices of the Federal laboratories. Below are listed some of the commonly used avenues for personnel exchange; however, more details can be obtained by contacting individual laboratories.

\section{Intergovernmental Personnel Act (IPA) Assignments}

The Intergovernmental Personnel Act (IPA) allows for the exchange of personnel between Federal agencies, state and local governments, institutions of higher education, federally funded research development centers, Indian tribal governments, and other nonprofit organizations. Through IPA appointments, exchanges would be paid by the Federal agency in which he or she is assigned and can receive Federal benefits and other applicable privileges. However, IPA details require for university personnel to ensure that their pay, allowances, and benefits are covered by their home institution. There are also bi-directional exchanges of personnel in which Federal S\&E employees can work at institutions of higher education to hopefully provide a new perspective on research projects and/or administrative tasks currently being conducted at universities.

\section{Joint Appointments}

Many universities offer joint appointment opportunities to their faculty, allowing them to split their time and efforts between multiple departments, universities, or other institutions. Accordingly, university faculty may have the opportunity to retain their position in their department while also holding an appointment as a researcher at a DOD laboratory. In addition, it is also possible for universities to offer joint appointments to 
DOD researchers to teach or conduct research under their institution without hiring them as full-time faculty. Joint appointees are considered employees of both institutions.

Faculty interested in obtaining a joint appointment to work with DOD laboratories should discuss with their heads of departments the feasibility of a joint appointment and negotiate the terms of the new appointment. Faculty should also verify with the employment office of the DOD laboratory with which they would like to work that there are availabilities for joint appointment research scientists and ensure that there are no conflicts-of-interest. Universities interested in hiring a DOD researcher as a joint appointee should contact individuals directly while communicating with the laboratory's Human Resources Department.

\section{Educational Agreements}

The DOD laboratories offer many educational opportunities for university students and even faculty-whether through summer internships/fellowships, opportunities to conduct research on unique equipment, or teaching partnerships. In some cases, universities and laboratories have found it mutually beneficial to co-develop curricula in science and engineering; doing so helps to ensure that the laboratories are supplied with a steady stream of well-trained, scientific talent while providing university students in relevant fields with reliable employment opportunities. In addition to standard Educational Partnership Agreements, each service and laboratory offers a range of unique fellowship, internship, or sabbatical leave programs.

\section{Educational Partnership Agreement (EPA)}

Students and other research faculty interested in participating in an exchange with DOD laboratories can also enter into contractual agreements known as Educational Partnership Agreements. Under an EPA, the laboratory may provide equipment and personnel for instruction at the institution, and allow faculty and students to participate in research projects at the laboratory. In addition, laboratory and university personnel can leverage an EPA to co-develop curriculum that suits the interest of both parties.

\section{Other Fellowship, Internship, and Sabbatical Leave Programs}

While EPAs are contractual agreements between universities and Federal laboratories, there are additional mechanisms for individual students and faculty to receive fellowships and sabbatical for temporarily conducting research in DOD laboratories. The Air Force Summer Faculty Fellowship Program, the United States Air Force/National Research Council - Resident Research Associateship (USAF/NRC-RRA) $\underline{\text { Program, the Naval Research Sabbatical Leave Program for faculty, and the College }}$ Qualified Leaders (COL) program for college students, graduate students, and post-docs are some examples of programs that give researchers an opportunity to conduct research 
at a DOD laboratory. Summer Fellowship programs last around 10 weeks, while Sabbatical Leave programs can be from one semester to a year. The CQL program for students is a paid internship that last for six months and more and is aimed at giving students STEM research experience while hoping to build a strong relationship between students and the Federal STEM research enterprise. Other student internships, which are aimed to spark interest in STEM and provide research experience, include the Gains in the Education of Mathematics and Science and the Science and Engineering Apprentice Program. Both are available in multiple laboratories, so students and faculty should check individual laboratory websites to find more information on the programs and application due dates. While there is no established program for unpaid internships at the DOD laboratories, students and faculty might inquire at specific laboratories.

\section{E. Other Partnership Agreements}

In addition to the above agreement mechanisms, there are also some additional partnership mechanisms that may appropriate for certain types of collaboration. These include UARCs and the Air Force COEs, both of which are long-term agreements for the development of advanced research centers. Both of these forms of partnerships may not be solicited by universities and are established under a competitive process via an open DOD solicitation notice. While they may not be solicited by universities, information is about these mechanisms is provided below for reference. In addition, for the case that none of the above agreement mechanisms are appropriate, the DOD maintains an Other Transaction Authority to tailor agreements with specific conditions on a case-by-case basis.

\section{University Affiliated Research Centers (UARC)}

Some universities have been able to form long-term partnerships with the DOD by developing UARCs. These centers are university-led research facilities, which are sponsored by the DOD to conduct cutting-edge research in fields essential for maintaining the engineering and technological capabilities of the U.S. Armed Forces. UARCs are usually housed within universities and facilitate collaboration between the laboratories within the university and the DOD as well as with private industry partners. UARCs are generally selected through competition by request of the DOD.

Industry participants aid some UARCS by leveraging their technology transfer and commercialization capabilities and through cost sharing efforts. UARCs are also funded under the exemption of 10 U.S.C. $\$ 2304(\mathrm{c})(3)(B)$, which allows the DOD to fund sole-source contracts outside of standard competitive procedures. There are currently 14 UARCs working with the DOD including the Army's UARC at the University of California at Santa Barbara's Institute for Collaborative Biotechnologies and the Navy's collaboration with University of Texas's Applied Research Laboratory. 


\section{Air Force Centers of Excellence}

The Air Force uses Centers of Excellence at universities as a partnership mechanism with universities in much the same way as the Army and Navy use UARCs. The Centers of Excellence fulfill a variety of research and technical needs ranging from basic research to training. Centers of excellence are competed through grants for up to five years.

\section{Other Transaction Authority (OTA)}

Other Transactions are not considered to be contracts, cooperative agreements, or grants, but an authority exercised by the DOD to enter into transactions for prototypes or research usually relating to weapons systems. The benefits of OTs is that they come with some reduction in government regulation such as FAR, and allow for advanced or additional payments rather than just cost-reimbursement. OTs can also be quite flexible in their contract terms. Non-Federal partners are generally required to provide at least one-third of the total cost of the project. Intellectual property requirements that are normally imposed through the Bayh-Dole Act do not apply to OTs and thus further IP protection terms must be negotiated. It is best to contact a Federal laboratory's Technology Transfer Office to inquire about OTs as they are not as quite as common as a partnering mechanism.

Universities wishing to engage in any of these partnership mechanisms should contact the laboratory with which they are interested in working. A list of laboratories and contacts is provided at the end of this guidebook. 


\section{FAQs on Working with DOD Laboratories}

Q: Where can I find out about collaborative opportunities with the laboratories?

A great place to start is with the Broad Agency Announcements (BAAs) of the DOD Laboratories. The BAAs will highlight collaborative opportunities that the laboratories are currently offering. BAAs can be found at grants.gov or on the websites of the laboratories (see the webpages of $\underline{\mathrm{ARL}}^{2} \underline{\mathrm{ONR}}^{3}$ and $\underline{\mathrm{AFOSR}^{4}}$ ).

The Technology Transfer Offices for the Army, $^{5}{ }^{5 a v y}{ }_{,}^{6}$ and Air Force, ${ }^{7}$ Laboratories are additional resources for learning about collaborative research opportunities.

\section{Q: What sort of research are DOD laboratories interested in collaborating on?}

DOD laboratories are interested in collaborating in specific areas of research that are closely tied to their mission areas and needs. ${ }^{8}$ Often times, fundamental research is critical for the laboratories to achieve their long-term goals. In addition, the laboratories may be able to contribute new ways of thinking or uses to existing ideas and processes developed under basic research As a result, DOD laboratories are often very interested in collaborating with universities even at a basic research level. Some laboratories are even specifically chartered to seek out collaboration with university scientists in order to create new linkages and engender new ideas.

\section{Q: I have an idea for a collaboration that is not currently being offered as a BAA.} Can I propose an idea?

Yes, researchers from DOD laboratories and universities have opportunities for informal face-to-face interaction at conferences and technical meetings, where ideas beyond those reflected in open BAAs can potentially be discussed. Informal forums for discussion are an avenue by which laboratories seek input from the community on new research areas where there is a potential for collaboration.

However, in order to establish formal research collaboration, universities and laboratories must go through the appropriate formal channels to address any applicable

2 http://www.arl.army.mil/www/pages/8/Mod2_ARL_BAA_revsept13.pdf.

3 http://www.onr.navy.mil/Contracts-Grants/Funding-Opportunities/Broad-Agency-Announcements.aspx.

$4 \mathrm{http}: / /$ www.wpafb.af.mil/library/factsheets/factsheet.asp?id=8127.

5 http://www $\cdot$ arl.army.mil/www/default.cfm?page $=521$.

${ }^{6}$ http://www.nrl.navy.mil/techtransfer/index.php.

${ }^{7}$ http://www.wpafb.af.mil/library/factsheets/factsheet.asp?id=6026.

8 http://www.dtic.mil/dtic/annualconf/2011/Labs.pdf, page 5 . 
Federal regulations. In addition, the arrangement of collaborative projects that are more extensive than single investigators cooperation (e.g., CRAs, CTAs, and UARCs) is a process that is largely dictated by laboratory's mission and resources and therefore cannot be offered in all fields. Accordingly, universities should not propose UARCs or CRAs that are not solicited in a BAA.

\section{Q: Are there security requirements for working with the laboratories?}

Yes. In order to serve the United States' research needs, DOD laboratories must ensure that the right security procedures are taken for work being done at the laboratories. This security pertains to research, personnel, and equipment at the laboratory facility. For example, DOD laboratories need to ensure that only properly verified personnel have access to critical facilities and research occurring at the laboratory.

The implications of these security requirements, however, will vary across different laboratories and areas of research. In some cases, collaborative research partners at a university may need to undergo a background check or obtain clearance. While some DOD research laboratories may be off-limits to outside researchers, some laboratories maintain separate areas with different classification requirements in order to facilitate access for university researchers; an example is the Army Research Laboratory at Adelphi, MD. A similar concept is employed at the Wright Brothers Institute ${ }^{9}$ in Dayton, $\mathrm{OH}$, an unclassified space where the public, private and academic sectors collaborate to work on complex and challenging problems for the Air Force Research Laboratories.

In general, security and clearance processes are largely manageable requirements. Universities seeking to interact with a laboratory should be cognizant of these restrictions and should engage with the laboratory to devise a solution that works for both parties.

\section{Q: I have foreign graduate students. Can they help me in my collaborative partnerships with the DOD laboratories?}

It depends. Some laboratories are able to grant access for foreign students involved in summer or collaborative research projects. Certain laboratories maintain distinct classification areas and access arrangements that help to accommodate foreign students involved in collaborative projects.

However, foreign students are ultimately unable to obtain security clearances, which precludes them from being hired into permanent positions by the DOD laboratories. ${ }^{10}$ Involvement of foreign students can typically only be determined on a case-by-case basis

\footnotetext{
9 http://wbi-icc.com/,

${ }^{10}$ For more detailed information on the hiring of foreign nationals at DOD laboratories, see the following report at https://www.ida.org/upload/stpi/pdfs/ida_d-4786final.pdf.
} 
that considers the laboratory, the nature of the agreement, the research being conducted, and the nationality of the student; overall, and getting students involved in the laboratories can be very challenging and in some cases, impossible,

\section{Q: Will I still be able to publish my research if I work with the DOD, or will my work be classified?}

Almost all of the research performed by a university under a collaborative agreement with a DOD laboratory is likely to be unclassified and publishable. In general, DOD laboratories and universities collaborate most often on basic or fundamental research, categorized in the military as 6.1 level research. At the 6.1 level, the research is not considered classified or sensitive. The DOD laboratories encourage university scientists to publish their basic research work; in fact, in many cases researchers on both sides of a laboratory-university partnership will team up to co-publish journal articles or present their findings at conferences. However, since regulations vary with the partnering Federal laboratory and nature of the collaborative research, universities and their researchers should always work with their respective offices that are responsible for external partnerships to review the Terms and Conditions applicable to the particular research agreement.

In some occasions, university researchers involved in research collaborations with DOD laboratories may be working on slightly more applied research questions, potentially at the 6.2 or 6.3 level. In these cases, the DOD laboratory may require the university researcher to submit their paper to the laboratory for review before publishing. In the majority of collaborations, this review does not impede the researcher's ability to publish.

\section{Q: How will the creation and assignment of any intellectual property be handled?}

Like all Federal entities, DOD laboratories face specific restrictions on how they can manage intellectual property (IP) that results from a collaborative effort. In general, non-Federal partners are allowed to retain rights to IP developed in conjunction with Federal partners like DOD laboratories. In fact, the terms of the Bayh-Dole and Stevenson-Wydler Acts specify that government bodies like the laboratory must allow non-Federal partners like universities to assume the title of IP generated under certain funding agreements or collaborative research programs. However, these laws also require that the government be allowed to retain a free license to use any of the IP generated.

In terms of copyright, DOD laboratories are prohibited from seeking copyright protection for their work. This may mean that collaborative research performed jointly between a laboratory and university cannot be eligible for copyright, which is often a preferred legal protection for software or other types of IP. However, laboratoryuniversity agreement can be arranged in advance to specify that the university retain IP and copyright protection for its part of the collaborative work. 
In general, open dialogue and engagement between the laboratory and the university can help to structure collaborative agreement in such a way as to handle any IP generated through collaboration.

\section{Q: What are government "march-in" rights?}

March-in rights entails the government's ability to re-assign IP in the case that a non-Federal party does not commercialize a technology that is imperative to the public welfare of the United States. This right can only be used in cases where (1) the nonfederal partner is assigned a license to IP but does not seek to commercialize it within a reasonable time as determined by the heads of the partner agency or his/her designee and (2) the commercialization of the IP is deemed to be necessary to public health and safety needs of the country.

To date, march-in rights have never been used to take IP away from a non-Federal party. While the vast majority of the potential collaborative basic research performed jointly by laboratories and universities is far from commercialization and will never be at risk of march-in, universities should be aware of this legal requirement for DOD laboratories.

\section{Q: Will any IP that I bring to the collaboration be protected?}

Yes. Generally, both parties would provide upfront their Background IP, i.e., the IP that was in existence prior to or is first produced outside of the formal agreement, while drafting the partnership contract. This IP would be protected from use outside of the execution of the agreement. For example, the standard template for the DOE CRADA has partners list their Background IP and states that while each party may use this specified Background IP for solely the performance of research specified by the CRADA, they will be unable to commercialize or otherwise use the other party's pre-existing IP.

\section{Q: Does working with a DOD laboratory affect the university's ability to file for a} patent?

Currently, conditions under the America Invents Act specify that a university loses its micro-entity status - which allows a university to apply for patents at reduced ratesif it is collaborating with an organization of the United States government like a DOD laboratory. While this does not affect research that is too early-stage for potential patenting, it may be a concern in instances where the university does hope to file a patent. At present, the Interagency Technology Transfer Working Group is seeking to promote amending the act so as to allow universities to retain their micro-entity status. More information on this endeavor can be found on the U.S. Patent and Trademark Office website. 


\section{Q: What other regulations do I need to know about to work with a DOD}

laboratory?

DOD laboratories are subject to a number of restrictions when entering into partnership with non-Federal entities. Some of these entail the following:

- DOD laboratories cannot indemnify a non-Federal party for any damages

- DOD laboratories must ensure that there are no conflicts of interest in signing agreements

- Funded agreements with DOD laboratories must be competed publically under fairness of opportunity

- Collaboration involving potential manufacturing of products or goods must show a preference for U.S. industry

- ADD: Review of third party participation should also be addressed.

Additionally, DOD researchers are subject to certain restrictions under the DOD joint code of ethics (e.g. traveling, receiving honorariums). Many of these Federal and agency requirements do not prove to be showstoppers in arranging a working collaboration between a DOD laboratory and a university, and negotiation between the two often leads to successful arrangements Additional information on some of these government regulations can be found in Appendix B.

\section{Q: Who do I contact for more information?}

The last section of this guidebook contains a list of DOD laboratories with their respective points of contacts. In addition, many of these laboratories have website with information on their research and on potential collaborations. 


\section{Benefits to Partnering with DOD Laboratories}

Scientific research is by its nature collaborative, and researchers often find that partnerships yield benefits to both parties involved. Accordingly, universities and DOD laboratories working in similar or even different research areas may find that collaborative research partnerships open new doors and help to further the research goals of each participant. In addition, the unique needs, facilities, and capabilities of both universities and DOD research laboratories suggests that each has a number of incentives for exploring partnership with the other. Some of the benefits of laboratory-university collaboration are provided below.

\section{Access to unique capabilities}

Many universities also maintain advanced research facilities that may further DOD laboratory work. In these cases, DOD laboratories might serve as a valuable user for university research facilities, while also contributing important research to areas of mutual interest. Opportunities extend outside of facilities as well, and partnerships can provide both universities and the laboratories with access to other capabilities such as scientific expertise and personnel or technical data sets that one of the two partners might not have available at their own organization.

\section{Guidance for existing research}

Universities may benefit greatly from the practical experience of the DOD laboratories in certain areas where the laboratories have invested decades of research and have a wealth of knowledge and expertise. Conversely, universities are able to respond quickly to the changing fields of research and often open up new programs in emerging research areas, and DOD laboratories can benefit from working with universities who are exploring the frontiers of new research. Collaborating allows both partners to take advantages of the unique strengths and capabilities of each other within or across fields of research.

\section{Opportunities for new research}

Collaboration with the DOD laboratories offer universities a chance to work on new areas and applications that may be outside the general purview of the field. For example, in the Chem-Bio area, working on specific applications in next generation filtration devices, sensors, fabrics, decontaminants, and other materials for chemical biological applications can also lead into new research areas. It also gives those universities 
interested in chemical biological agents a chance to test their hypotheses and materials against live Chem-Bio agents, an opportunity that is not readily available elsewhere. Collaborations are very beneficial in new, multi-disciplinary and fast evolving research areas such as cyber-security where, for instance, university legal and policy experts might team up with DOD researchers working on information technology to explore new dimensions of the field. Similarly, partnerships may enable universities and laboratories to address new research that may have dual use implications.

\section{Leveraged outcomes and funding}

Working with laboratories also may serve to help universities leverage additional research funding from the DOD. Patents and inventions can be developed and shared jointly, providing benefits to both parties while relieving either party from having to pay the full cost need to achieve a development. In collaboration, laboratory and university researchers may identify spin-off basic research ideas that have military application and could be considered for additional funding from DOD grant funding offices. Partnerships between DOD laboratories and universities might also be able to respond to solicitations that either party may not be able to pursue on its own, offering additional opportunities for research funding.

\section{Opportunities for students}

Research partnerships can also provide exciting employment opportunities for university students interested in honing their talents and probing scientific challenges. Students involved in collaborative projects will find potential access to summer or postgraduate research position at DOD laboratories. Students learn about research that is important for the DOD, and university-industry collaborations are a great way to develop the pipeline of students in defense related research. In addition to benefiting universities by helping to secure research positions for its graduates, the laboratories benefit by increasing their exposure to top-level research talent coming out of the universities. Accordingly, both universities and laboratories may find benefits to involving students in collaborative research projects. 


\section{Notable Partnership Examples}

The benefits of collaboration between universities and DOD laboratories are best shown through the positive outcomes and achievements of past cooperative efforts. Outlined here are several ongoing cooperative projects that have had notable outcomes that reflect the wide span of accomplishments possible through research partnership.

\section{Education partnerships with NSWC Crane}

The Naval Surface Warfare Center-Crane Division has been at the forefront of developing cooperative educational programs with universities. These programs serve not only to build the skills and talents needed for the research being done by the Navy, but also help to strengthen students' intellectual tools, prepare researchers for the outside world, and improve the community that Crane serves.

One piece of Crane's educational collaboration with universities involves MBA and other business programs at Baylor, Southern Indiana, and Ball State Universities. Through Partnership Intermediary Agreements, Crane recruits graduate students from these schools to help write patent applications for inventions at the laboratory, giving students real world experience while completing their graduate business degree. Crane also has Educational Partnership Agreements with nearby universities that enable it to work with academic partners to develop curricula in technical areas relevant to both the laboratory and the university. In some cases, Crane will pay for students to earn their Master's degree in desirable fields. These programs benefit the students they involve and are working to further the missions of both the laboratory and the university.

\section{ECBC surface chemistry collaboration}

One successful example of a collaborative project in basic research is that between the U.S. Army Edgewood Chemical Biological Center (ECBC) and the Virginia Polytechnic Institute. The idea of collaborating began when a Virginia Tech. professor began some basic discussions with researchers from ECBC about surface chemistry and nano-scale materials. Eventually, as interest in collaborating grew on both sides, a Cooperative Agreement between the two was signed, formalizing the agreement.

In terms of research, the partnership between the two has so far proven mutually beneficial: using laboratory facilities, the university professor has been able to test new instrumentation and analytical capabilities that are also of interest to ECBC from a basic research standpoint. In addition, the collaboration has provided fruitful training experience 
for Virginia Tech. graduate students and post-docs, who work anywhere from a week to six months at the lab. A few of them have even gone on to work at or with the laboratory after graduation. In addition to joint publications being produced, the two partners have leveraged each other strengths to move forward in this area of common interest.

\section{AFRL University Partnerships}

The Air Force Research Laboratory (AFRL) is headquartered at Wright-Patterson Air Force Base in Ohio. In order to stay engaged with the local academic expertise and talent, it has developed a number of collaborative research programs with neighboring universities and graduate schools. These partnerships serve to advance both AFRL and the university's research and education goals.

One vehicle of this partnership is a Cooperative Agreement with Dayton Area Graduate Studies Institute. Signed in 2012, the agreement provides funding from AFRL to support graduate science and engineering faculty and students conducting research in areas of interest to the laboratory. The funding is flexible and can be used for a variety of expenses, including tuition, stipend, travel, and publishing fees. Another partnership is a CRADA signed between the University of Dayton Research Institute and AFRL. The agreement allows commercial companies (such as university spin-offs) to use AFRL laboratory resources and facilities to test research or designs relevant to AFRL's mission.

\section{Electric Ship Research and Development Consortium (ESRDC) \\ Original funding source: Office of Naval Research}

The Florida State University together with seven major research universitiesMassachusetts Institute of Technology, Mississippi State University, Purdue University, University of South Carolina, the University of Texas at Austin, the United States Naval Academy, and the United States Naval Post Graduate School constitutes the Electric Ship Research and Development Consortium (ESRDC) and have performed successfully as a consortium since 2002. Each institution has brought unique capabilities, and they are working at the leading edge of the important emerging technologies for the all-electric ship (AES). The Consortium provides the Navy and industry access to world-class research resources and a broad range of research capabilities not obtainable from a single institution. The ESRDC has developed design and assessment tools and experimental facilities that are unique for assessing the Science and Technology (S\&T) issues associated with the design of the next generation AES. The ESRDC has also provided the researchers and the students with the opportunity to work as teams on interdisciplinary projects, and with a broader view of the technology options than would be possible at a single institution. Each university member also has strong industry collaborations. 
The Navy's technology development approach involves industry, the Navy's laboratories, and universities. This is an important investment in domestic capability, as significant technical capability in electric ship technology exists outside of the United States due to early investment in commercial electric ship technologies in other countries. The industrial participants are developing the technologies they can incorporate into ships in the near term. Their near-term focus is appropriate, as they have a responsibility to their stockholders to focus on projects that return profits to the company. The Navy facilities and staff members are playing a key role by evaluating emerging technologies to influence the technology early enough in the development cycle to minimize implementation and ownership costs for the Navy. The universities are assessing longerterm options and producing students who understand electric ship technology and can be future leaders in the companies and Navy laboratories. The ESRDC has developed a comprehensive understanding of the challenges facing shipbuilders, the Navy, and the country today. 


\section{References}

National Research Council (NRC). National Laboratories and Universities: Building New Ways to Work Together-Report of a Workshop. Washington, DC: The National Academies Press, 2005. http://www.nap.edu/catalog/11190.html.

- - Assuring the U.S. Department of Defense a Strong Science, Technology, Engineering, and Mathematics (STEM) Workforce. Washington, DC: The National Academies Press, 2012. http://www.nap.edu/catalog.php?record_id=13467.

Results of the 2012 Faculty Workload Survey, presented at the Federal Demonstration Partnership meeting, January 2013, Washington DC, http://sites.nationalacademies.org/PGA/fdp/PGA_081164. 



\section{Abbreviations}

\begin{tabular}{|c|c|}
\hline AFOSR & Air Force Office of Scientific Research \\
\hline AFRL & Air Force Research Laboratory \\
\hline AHPCRC & Army High Performance Computing Research Center \\
\hline ARDEC & $\begin{array}{l}\text { Army Research, Development and Engineering } \\
\text { Command }\end{array}$ \\
\hline ARO & Army Research Office \\
\hline ARL & Army Research Laboratory \\
\hline $\mathrm{ASD}(\mathrm{R} \& \mathrm{E})$ & $\begin{array}{l}\text { Assistant Secretary of Defense for Research and } \\
\text { Engineering }\end{array}$ \\
\hline BIO-MIMETICS & $\begin{array}{l}\text { Barrier-Immune-Organ: Microphysiology, } \\
\text { Microenvironment Engineered Tissue Construct } \\
\text { Systems }\end{array}$ \\
\hline CEIMM & Centers of Excellence on Integrated Materials Modeling \\
\hline CENTEC & $\begin{array}{l}\text { Center of Excellence in Neuroergonomics, Technology, } \\
\text { and Cognition }\end{array}$ \\
\hline CNARC & Communications Networks Academic Research Center \\
\hline $\mathrm{COI}$ & conflict of interest \\
\hline CQL & College Qualified Leaders \\
\hline CRA & Collaborative Research Alliance \\
\hline CRADA & Cooperative Research and Development Agreement \\
\hline CTA & Collaborative Technology Alliance \\
\hline DARPA & Defense Advanced Research Projects Agency \\
\hline DOC & Department of Commerce \\
\hline DOD & Department of Defense \\
\hline DOE & Department of Energy \\
\hline ECBC & Edgewood Chemical and Biological Center \\
\hline EVPR & Executive Vice President for Research \\
\hline FAR & Federal Acquisition Regulation \\
\hline FDC & Flexible Display Center \\
\hline FFRDC & Federally Funded Research and Development Center \\
\hline GMU & George Mason University \\
\hline GOCO & government-owned, contractor-operated \\
\hline GOGO & government-owned, government operated \\
\hline IAWGTT & Interagency Working Group on Technology Transfer \\
\hline INARC & Information Networks Academic Research Center \\
\hline IRC & Interdisciplinary Research Center \\
\hline IDA & Institute for Defense Analyses \\
\hline IP & intellectual property \\
\hline IPA & Intergovernmental Personnel Act \\
\hline ITAR & International Traffic in Arms Regulations \\
\hline
\end{tabular}


MACEEP

MAST

MIT

MOU

MURI

MUKRC

NASA

$\mathrm{NIH}$

NIST

NSF

NSSEFF

NSWC

NRC

OMB

ORTA

OSD

OSTP

PI

PM

R\&D

RRA

S\&T

SFFP

SNA

SNARC

STEM

STPI

TARDEC

U.S.

U.S.C.

UARC

UCLA

URL

USAF
Michigan/Air Force Center of Excellence in Electric

Propulsion

Micro Autonomous Systems and Technology

Massachusetts Institute of Technology

memorandum of understanding

Multidisciplinary University Initiative

Michigan Technological University Keweenaw

Research Center

National Aeronautics and Space Administration

National Institutes of Health

National Institute of Standards and Technology

National Science Foundation

National Security Science and Engineering Faculty

Fellows

Naval Surface Warfare Center

National research Council

Office of Management and Budget

Office of Research and Technology Applications

Office of the Secretary of Defense

Office of Science and Technology Policy

principal investigator

program manager

research and development

Resident Research Associateship

science and technology

Summer Faculty Fellowship Program

Social Network Analysis

Social/Cognitive Networks Academic Research Center

Science, Technology, Engineering and Mathematics

Science and Technology Policy Institute

Tank Automotive Research, Development and

Engineering Center

United States

United States Code

University Affiliated Research Center

University of California, Los Angeles

uniform resource locator

United States Air Force 


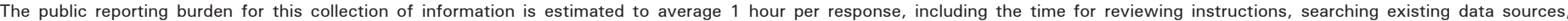

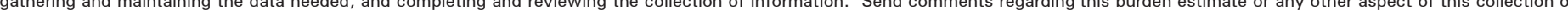

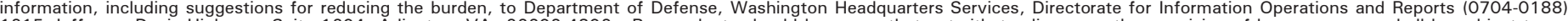

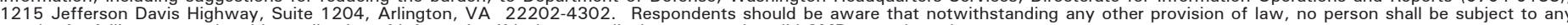
penalty for failing to comply with a collection of information if it does not display a currently valid OMB control number.

PLEASE DO NOT RETURN YOUR FORM TO THE ABOVE ADDRESS.
1. REPORT DATE (DD-MM- $Y Y Y Y)$
2. REPORT TYPE
Final
XX-07-2014

4. TITLE AND SUBTITLE

Research Collaborations Between Universities and Department of Defense Laboratories

5a. CONTRACT NUMBER

NSFOIA0408601

5b. GRANT NUMBER

5c. PROGRAM ELEMENT NUMBER

\section{AUTHOR(S)}

5d. PROJECT NUMBER

Gupta, Nayanee

Sergi, Brian J.

Tran, Emma D.

Nek, Rashida

Howieson, Susannah V.

5e. TASK NUMBER

TP-20-1000.00.AU

5f. WORK UNIT NUMBER

\section{PERFORMING ORGANIZATION NAME(S) AND ADDRESS(ES)}

IDA Science and Technology Policy Institute

1899 Pennsylvania Avenue, NW, Suite 520

Washington, DC 20006-3602

\section{SPONSORING/MONITORING AGENCY NAME(S) AND ADDRESS(ES)}

Office of Science and Technology Policy

Eisenhower Executive Office Building

1650 Pennsylvania Ave, NW

Washington, DC 20500

\section{DISTRIBUTION/AVAILABILITY STATEMENT}

Approved for public release; distribution is unlimited (31 July 2014).

\section{SUPPLEMENTARY NOTES}

\section{ABSTRACT}

This document examines the current landscape of research partnerships between Department of Defense (DOD) laboratories and universities, with the goal of recommending steps to reduce barriers faced in these undertakings and to increase the number of collaborations between the two entities. The work was is informed by structured discussions with members of the research community as well as research leaders, both at universities and at DOD laboratories. The factors contributing to the barriers are delineated and recommendations for policy actions to change the status quo are made.

15. SUBJECT TERMS

Department of Defense (DOD), Federal Laboratories, University-Federal partnerships, collaborative research

\begin{tabular}{|c|c|c|}
\hline \multicolumn{3}{|c|}{ 16. SECURITY CLASSIFICATION OF: } \\
\hline a. REPORT & b. ABSTRACT & c. THIS PAGE \\
Unclassified & Unclassified & Unclassified \\
\hline
\end{tabular}

\section{LIMITATION OF} ABSTRACT

Same as Report
18. NUMBER OF PAGES

67 19a. NAME OF RESPONSIBLE PERSON Skaggs, Reed 19b. TELEPHONE NUMBER (Include area code) 202-456-3653 